\title{
LOS ENTRESIJOS DE LA DIGNIDAD HUMANA
}

\section{THE HIDDEN DETAILS OF HUMAN DIGNITY}

\author{
Jesús Victor Alfredo Contreras Ugarte \\ Doctor Sobresaliente Cum Laude en Derechos Humanos \\ Académico de la Real Academia de Jurisprudencia y Legislación \\ de España Departamento de Derecho Internacional, \\ Eclesiástico y Filosofía del Derecho \\ Facultad de Derecho - Universidad Complutense de Madrid \\ jesuco_amag@yahoo.es \\ España, Madrid
}

\section{SUMARIO}

- La dignidad humana y su inextricable entender.

- Trayecto conceptual de la dignidad humana.

- La dignidad y las normas de derechos humanos.

- La dignidad de uno frente a la dignidad del otro: Empatía del Reconocimiento.

- Conclusiones.

\section{RESUMEN}

La dignidad humana supone entender al ser humano como un ser que, por sus específicas características que le son propias a la condición humana, tiene un valor especial que impone que se le dé el reconocimiento y el respeto por parte de la sociedad. El ser humano se situaría en el centro del mundo, ocupando un lugar preeminente con respecto al de los demás seres. Siendo así, hablar de una dignidad humana de todos e igual para todos en tanto humanos, supone situarnos en una visión universal y unificada en cuanto a lo que es ella. Aquí pues, empieza el problema. Es fácil encontrar referencias a la dignidad humana en muchas normativas, sobre todo de derechos humanos, tanto en normas nacionales como en normas internacionales. En estas normas nos toparemos, con mucha facilidad, con el uso del término dignidad repetido varias veces y para sustentar un determinado derecho o argumento legal, pero no para definir qué es precisa y propiamente la dignidad humana. Luego, todo va bien mientras damos por sentado que todos sabemos y entendemos por igual lo qué es la dignidad; sin embargo, cuando haces la pregunta directa ¿qué es la dignidad humana? el asunto ya no es tan claro para todos por igual ni hay uniformidad en lo que se entiende por ella o, lo que es peor, simplemente adviertes que, realmente, no saben lo que es y que nunca reflexionaron sobre ello. Aquí descubres este entresijo que no es fácil de clarificar. Casi parece un atolladero que unos resuelven de una forma, otros de otra y otros de ninguna. Este trabajo intentará dar luz para la clarificación de esta complicación conceptual.

\section{ABSTRACT}

Human dignity means understanding human beings as beings that, due to its specific characteristics that are specific to the human condition, has a special value that requires recognition and respect from society. Human being would be placed in the center of the world, occupying a preeminent place with respect to the other beings. Thus, speaking of a human dignity of all human beings, equal for all as human beings, supposes placing ourselves in a universal and unified vision as to what it is. Here then, the problem begins. It is easy to find references to human dignity in many regulations, especially in human rights, both in national and international norms. In these regulations we will find, easily, the use of the term dignity repeated several times to sustain a certain right or legal argument, but not to define what is precisely and properly human dignity. Then, everything goes well as far as we assume that we all know and equally understand what dignity is; However, when you 
ask a direct question on what is human dignity? the issue is not as equally clear for everyone, nor is there uniformity in what is understood by it or, what is worse, you simply notice that they really do not know what it is and that they have never reflected on it. Here you discover this intrigue that is not easy to clarify. It seems a problem that some resolve one way, others in another and others do not. This work will try to shed light for the clarification of this conceptual complication.

\section{PALABRAS CLAVE}

Dignidad humana; entresijo conceptual; derechos humanos; empatía del reconocimiento.

\section{KEYWORDS}

Human dignity; conceptual problems; human rights; empathy of recognition.

\section{LA DIGNIDAD HUMANA Y SU INEXTRICABLE ENTENDER}

La dignidad es un término que suele usarse como sinónimo de corrección, de valoración o de respeto. Cuando se hace algo que se considera incorrecto y malo se suele decir que esa persona ha actuado indignamente o de manera no digna. O cuando describimos la mayor valoración que consideramos de alguien, solemos decir que esa persona es digna para estar donde está y hacer lo que hace, decimos que es digno para ello. Asimismo, cuando hablamos de respeto hacia nuestros derechos como persona, solemos decir que tenemos derechos a tener una vida digna o una vivienda digna, etcétera, y no dudamos en afirmar que todas las personas tenemos dignidad. De alguna forma, parece ser que todos tienen sobresabido qué es la dignidad propiamente dicha. Sin embargo, cuando preguntas, te das cuenta que cada quien tiene una idea distinta de lo que entiende por dignidad y otros ni siquiera pueden dar una definición precisa. Todos, en principio, aceptan, con firmeza, que la dignidad es inherente a todo ser humano por ser tal; sin embargo, cuando sometes esta firmeza a determinados escenarios -como por ejemplo en el caso de un pedófilo o un asesino- ya esto no resulta nada claro y caen en tremendas contradicciones. Esto se da, porque su concepto de dignidad lo manejan ambiguamente $\mathrm{o}$, simplemente, porque nunca se han preocupado por entenderlo y lo usan por mera repetición de lo que intuyen, ven u oyen en su entorno.

Esto hace que el concepto de dignidad humana resulte confuso y con muchas dificultades y enredos que resultan difíciles de desatar y entender. Está claro entonces, que el concepto de dignidad es un concepto que necesita ser aclarado en nuestra ética contemporánea $\mathrm{y}$ que no es nada fácil hacerlo dado los sobreentendido que muchos parecen tener de ello. Y esto pasa en todos los ámbitos, también en los profesionales e incluso en los académicos. El vocablo dignidad es muy utilizado, pero con significados, muchas veces, distintos. Se utiliza el mismo significante, pero no siempre se tiene un mismo significado de lo que se entiende por dignidad.

Por otro lado, es interesante advertir la importancia que se le da al vocablo dignidad en el cuerpo de los textos legales, tanto nacionales como internacionales. $\mathrm{Si}$ observamos la Declaración Universal de los Derechos Humanos y la cotejamos con otros Códigos deontológicos o con otras Cartas, Convenios y Pactos internacionales de Derechos, e incluso con las Constituciones internas de los países, nos vamos a encontrar que la palabra dignidad es una referencia común en todas ellas. No obstante, en todos estos cuerpos legales nunca se define lo qué es, precisa y propiamente, la dignidad como tal, es decir, cuál es el concepto que la define a ella. Parece ser que se da por sobreentendido el significado de la dignidad y lo que, dicho vocablo, evoca o debiera evocar, aunque, claro está, tampoco se trata de que los textos legales tengan que definir el significado de cada uno de los vocablos que los integran. Lo que aquí trato de advertir es que este vocablo es el más utilizado y repetido por la mayoría de los textos legales que regulan derechos, y esto, al menos, me lleva a tener el recelo de que el término dignidad se haya convertido en nada más que un vocablo usado decorativamente para dar una imagen de toma de seriedad hacia la protección de los derechos, pero que no pasa de ser una imagen estética que solo busca parecer, aunque no llega a ser de verdadera seriedad ni de preocupación real para los operadores específicos de este tipo normas. Lo que sí debe de ser claro es que la dignidad humana es el impulso generador de los derechos y, con ellos, de los derechos humanos. No nos desorientemos en algo que es básico para abrirnos camino en la idea de 
alcanzar, al menos, un concepto mínimo de la dignidad como tal. Los derechos son los que dan cobertura a la dignidad; la dignidad humana es la impulsora y la fuente motora de los derechos que se regulan en la sociedad:

(...) la dignidad no debe confundirse ni con los derechos, ni con el juicio de igualdad, razonabilidad o ponderación de los derechos mismos; por el contrario, ésta se identifica como el 'instrumento' que pone en funcionamiento unos y otros, constituyendo el 'motor' y el parámetro con respecto al cual ésos derechos se aplicarán correctamente. (Veronesi trad. por Gomez2015, página 157)

De no existir una idea concreta de lo que es la dignidad como tal y, peor aún, si su uso es solo decorativo, cada quien hará su propia interpretación o tendrá su propio sobreentendido de lo que es la dignidad, provocándose así que se tengan distintas interpretaciones según conveniencia o sobreentendido, y, con ello, no existirá uniformidad sobre lo que es la dignidad y, lo que es todavía más malo, es que se darán distintas formas de aplicación, de interés y de atención, a la hora de ventilar un mismo cuerpo legal de regulación de derechos.

Esta situación puede terminar haciendo que la dignidad humana se convierta en un concepto vacío de contenido que, aunque incorporado en los textos legales, no surta mayor efecto, más que el meramente estético.

$\mathrm{Si}$ nos remitimos a su etimología la palabra dignidad provendría de una lengua indoeuropea de los textos sagrados y cultos del brahmanismo, en la India, que es la conocida como sánscrito. $\mathrm{Su}$ raíz entonces sería la palabra dec, que significaría ser adecuado o conveniente a algo o alguien. Luego, este término, lo asumiría la lengua latina la que, incorporándole el sufijo mus, lo convirtió en el vocablo decmus, que más tarde se deduciría en dignus, que significaría algo así como destacado, y que, en castellano, se transformó en digno. El adjetivo dignus al significar destacado, implícitamente se le relacionó con valioso, originándose así, el término que hoy conocemos como dignidad humana; es decir, valiosos por nuestra humanidad y con una cierta “(...) preeminencia o excelencia por la cual algo resalta entre otros seres por razón del valor que le es exclusivo o propio" (MillánPuelles 1984, página 457).
En un primer momento, la dignidad se asentaba meramente en el estatus político y social. Después, en el Medioevo, esto siguió siendo así. Notemos que, en sus inicios, la dignidad no estaba referenciada a una cualidad inherente, propia e intrínseca al ser humano, sino que se reflejaba en el estatus o distinción social que se le reconocía y que alcanzaba cada persona; la dignidad de una persona se encontraba supeditada a situaciones extrínsecas a la condición misma de ser humano. En un segundo momento, con el Renacimiento, surgen una serie de posturas filosóficas hacia el siglo XVI, que le otorgan al ser humano un rol protagónico y superior, pero por razón de su ser y por ser hecho a imagen y semejanza de Dios; así pues, la dignidad renacentista consustancial al ser humano, pero la misma provenía de Dios. No deja de ser importante, de todos modos, el cambio de visión surgido en al Renacimiento que ya vislumbraba lo que podemos llamar el: antropocentrismo filosófico de la humanidad. Luego vendrán autores, a partir del siglo XVII, como ese al que llamo Hegel héroe del pensamiento, y pondrán en duda toda esa reflexión que, aunque ponían en el centro de la atención filosófica al ser humano, finalmente se sostenían en el pensamiento teologal, lo que podría parecer más bien, que estábamos frente a un teocentrismo y no ante un antropocentrismo. René Descartes fue un pionero en el intento de desligar a Dios de la explicación de la realidad externa del ser humano (la res extensa), y desde su conocida obra, de 1637, El discurso del método, trató de poner en tela de juicio todo ese sustento teologal; sin embargo, al final no lo logra del todo porque termina sustentando la realidad -a través de la figura de un genio maligno- en la idea de la perfección que hay en nosotros, pero que finalmente él la explica y la sustenta en la perfección divina:

(...) de dónde había aprendido yo a pensar en algo más perfecto de lo que yo era; y conocí con toda evidencia que debía ser de alguna naturaleza que en efecto fuera más perfecta (...) una naturaleza que fuera realmente más perfecta de lo que yo era, e incluso que tuviera en sí todas las perfecciones de que yo pudiera tener alguna idea, es decir, para explicarme con una palabra, que fuese Dios. (Descartes trad. por Alonso 1982, página 51 y 52) 
De lo anterior, se puede decir, que es una forma de aflojar en el intento cartesiano de desligarse de lo teologal; empero, el hecho de atreverse a dudar sobre el sustento divino de toda la realidad humana, sí que fue todo un gran aporte, es decir, el hecho de haber planteado la posibilidad de la duda en sí; tal era la pretensión de Descartes, que El discurso del método lo escribió en francés para que todos lo entendieran (en ese entonces la escritura culta se hacía solo en latín y, claro, solo podía leerlo la sociedad culta que lo sabía) y, además, lo escribió en Holanda, que era un país donde se podía escribir con mayor libertad, lejos de la persecución de la iglesia católica.

En fin, más allá de Descartes, podemos advertir que la dignidad se sustentó, en un determinado momento de la historia, en la dependencia de determinados hechos o condiciones extrínsecas alcanzadas, lo que proporcionaba a cada sujeto una distinta dignidad; y, luego, la dignidad se sustentó en el intrínseco valor del ser humano por su misma cualidad de ser tal. En definitiva, tanto en uno como en otro momento histórico, la dignidad humana, parte siempre desde la idea de lo valioso, sea intrínseca o extrínsecamente.

En nuestra modernidad, cuando hablamos de dignidad, ya no solo nos referimos a la dignidad como algo inherente a nosotros, sino que la hemos incorporado al ámbito jurídico, más precisamente, al ámbito del derecho positivo $\mathrm{y}$, muy especialmente, al de los derechos humanos. Se dice ahora, desde las normas jurídicas, que los derechos humanos se inspiran en la dignidad humana, en su respeto y protección, y que son características propias de ellos el ser inalienables, universales y absolutos. Esto supone que los derechos humanos, que dan soporte a la dignidad humana, no pueden nunca objeto de intercambio ni pueden ser meramente utilizados como medios de otros fines subalternos; supone que no tienen precio o valor equivalente y no deben estar subordinados por completo a ningún fin que los coloque en una situación de peligro o de detrimento; en cambio, los derechos humanos $\mathrm{y}$, con ellos, la dignidad humana, sí pueden ordenar medios para sí mismos y establecerse fines. El ser humano, actualmente, tiene dignidad la merezca o no, la trabaje o no. La dignidad supone la conciencia de cada persona de ser un sujeto digno, de saberse un ser valioso por su misma humanidad, de entender que por nuestra valiosa dignidad tenemos que ser personas responsables, consideradas y respetuosas con la dignidad de los demás, a los que nos encontramos innegablemente vinculados. La dignidad no es un privilegio ni un capricho que asumo y gozo sin comportarme según mi deber responsable para con los demás. Si bien, el no cumplir con este deber no supone la pérdida de la dignidad, sí hace que mi comportamiento resulte fuera de lugar $\mathrm{y}$, ello, me traerá consecuencias que, incluso, podrían afectar mi propia dignidad, además de la dignidad de los demás. También, el Estado debe inhibirse de ejercitar cualquier acto u omisión que ponga en peligro o que atente contra la dignidad y contra los derechos humanos; asimismo, debe garantizar las condiciones mínimas para que los ciudadanos logren alcanzar una vida digna dentro de sus sociedades.

\section{TRAYECTO CONCEPTUAL DE LA DIGNIDAD HUMANA}

El concepto de dignidad humana tiene un recorrido histórico que en su trajinar ha respondido a determinadas ideas de connotados pensadores que de una $\mathrm{u}$ otra manera han buscado centrar y precisar aquello que constituye o hace digna a una persona. En esta parte pretendo hacer un seguimiento del camino histórico-conceptual por el que ha marchado la dignidad humana y aunque no pueda ser un seguimiento riguroso ni completo ya que no me lo permite la amplitud que resiste este tipo trabajo, sí pretendo ser claro para alumbrar suficientemente la explicación de esta institución y de su concepto.

Si dirigimos nuestra atención al Renacimiento italiano, nos encontraremos con Pico Della Mirandola (1978) y su llamado Discurso sobre la dignidad del hombre, compuesto hacia 1486. Este Discurso (también llamado Oración), aunque formaba parte de una obra mayor -de la que era su presentación (conocida como las 900 Tesis o Conclusiones)-, toma especial relevancia cuando nos acercamos al desarrollo histórico del concepto de dignidad humana. Para Pico Della Mirandola (1978) la dignidad es un atributo perteneciente y característico de la cualidad humana. Dicho atributo se sustentaría en la potencia de sus capacidades naturales que como ser humano tiene y que le habilita para ejercer unas actuaciones y aptitudes que no poseen los demás seres de la creación. Para este autor el ser humano no 
ocupa un lugar estático en el mundo ya que está dotado del genio de poder optar, por sí mismo, su emplazamiento existencial dentro de la creación y, además, es capaz de llegar a sus metas desde sus potencias y capacidades. Todo esto, al ser humano, lo hace distinto a los demás seres pues ellos están invariable y permanentemente determinados en el mundo. Siendo así, resulta que el ser humano puede alzarse al nivel de los espíritus divinos, mas, asimismo, podrá descender a lo más bajo de la existencia, cual si fuera una bestia. Entonces, para Pico Della Mirandola (1978) la dignidad humana se sustentaría en el hecho de que el ser humano es un ser con atributos dinámicos, activos y en movimiento que se reflejan en su disposición y genio de poder alzarse en razón de sus potencias y capacidades otorgadas por Dios. De esta manera Dios nos ha situado dignos en el mundo:

(...) no te he dado ni un lugar determinado, ni un aspecto propio, ni una prerrogativa peculiar con el fin de que poseas el lugar, el aspecto y la prerrogativa que conscientemente elijas y que de acuerdo con tu intención obtengas y conserves. La naturaleza definida de los otros seres está constreñida por las precisas leyes por mí prescriptas. Tú, en cambio, no constreñido por estrechez alguna, te la determinarás según el arbitrio a cuyo poder te he consignado. Te he puesto en el centro del mundo para que más cómodamente observes cuanto en él existe. No te he hecho ni celeste ni terreno, ni mortal, ni inmortal, con el fin de que tú, como árbitro y soberano artífice de ti mismo, te informases y plasmases en la obra que prefirieses. Podrás degenerar en los seres inferiores que son las bestias, podrás regenerarte, según tu ánimo en las realidades superiores que son divinas. ¡Oh suma libertad de Dios padre, oh suma y admirable suerte del hombre al cual le ha sido concedido el obtener lo que desee, ser lo que quiere!. (Della 1978, páginas 48 y 49)

Ubicándonos en el Renacimiento español, nos encontraremos con Fernán Pérez de Oliva y su Diálogo de la dignidad del hombre. Esta obra se publicó, póstumamente, en el año 1546. El argumento de la obra consiste en enfrentar al ser humano con su situación en el mundo. A la actitud desesperanzadora y materialista se le contrapone la percepción del ser humano como ente creado por Dios a su imagen y semejanza con lo cual, Dios, cobra un lugar protagónico porque todo brota de él y es él quien otorga la dignidad al ser humano. En la obra de Pérez de Oliva se ve implícita una idea humanista en donde el ser humano tiene un rol secundario cuya apreciación estará determinada por la bondad de Dios de consentir a la naturaleza humana como digna. Con esto, es claro que Pérez de Oliva mantiene una visión teologal y teocéntrica de la dignidad y de la realidad del ser humano, cosa que no debe de extrañar ya que en la edad media esa era la idea preponderante. Pérez de Oliva defiende entonces un humanismo teocéntrico en donde Dios es quien determina con su dulzura, benevolencia y benignidad, la dignidad del ser humano; dicho de otra forma, para Pérez de Oliva, la dignidad del ser humano estaría sustenta en Dios porque el ser humano ha sido creado a su imagen y semejanza: «(...) la verdadera visión humanista sobre el particular es la síntesis dialéctica entre la dignidad y la miseria del hombre, montada sobre el eje del libre albedrío» (García 2010, página 115). No se puede negar cierta influencia que parece haber tenido la obra de Pico della Mirandolla sobre la obra de Fernán Pérez de Oliva, en lo que respecta a su concepto de dignidad y que se ve reflejado en la idea aquella de que el ser humano es un plan capaz de hacerse a sí mismo, y por ello, potencialmente capaz de ser todas las cosas, según él se determine:

(...) dijo Dios: Hagamos el hombre a nuestra imagen y semejanza (...) la imagen es de la esencia, y la semejanza es del poder y del oficio. (...) Dios tiene en su poderío la fábrica del mundo, y con su mando la gobiernan, así el ánima del hombre tiene el cuerpo subjecto, y según su voluntad lo mueve y lo gobierna (...) es manifiesto ser el hombre cosa universal, que de todas participa. (...) Dios en sí tiene de la perfección universal (...) el hombre tiene en sí natural de todas las cosas, así tiene libertad de ser lo que quisiere. (...) puso Dios al hombre acá en la tierra para que primero muestre lo que quiere ser; $y$ si le placen las cosas viles y terrenas, con ellas se queda perdido para siempre, y desamparado; más si la razón lo ensalza a las cosas divinas, o al deseo de ellas, y cuidado de gozarlas, para él están guardados aquellos lugares del cielo (...). (Fernán 1927, páginas 60 y 62) 
Como vemos, en la obra de Pérez de Oliva se realza la individualidad del ser humana y su libertad para determinarse en su realidad. Si nos damos cuenta, el Diálogo de la dignidad del hombre, de Fernán Pérez de Oliva, se enmarca en la idea de la potestad del ser humano de obrar por reflexión y elección, en donde el ser humano, por su libre albedrío, es un ser empoderado en sí mismo y por sus propias facultades, las que le son concedidas por Dios. Esto lo advertimos también en su Discurso de las potencias del alma y del buen uso dellas:

(...) la libertad del alma tiene en su mano el gobernalle de nuestra navegación, con el cual do quiera que se halle, nos puede encaminar a cualquiera parte de virtud, o del vicio. Así el libre albedrío es aquel cuyo poderío es el género humano señor de sí mismo, y cada hombre tal cual el quisiere hacerse. (Fernán 1927, página 95)

Laépoca renacentista es en la que se circunscribe el Diálogo de la dignidad del hombre, donde si bien es reflejo de esa contraposición humanista entre lo que era la miseria del ser humano frente a su potencial dignidad; sin embargo, esta obra también comporta una reflexión y una invocación hacia el deber y el compromiso moral. El Discurso declara una desilusión de derrotismo frente a la desgraciada situación humana en la que está expectorada nuestra realidad propia. Luego, en el mismo Discurso, se contrapone un argumento que no cae en la futilidad de centrarse a ensalzar las grandezas del ser humano, sino que se argumenta una invocación hacia el actuar responsable. En el Discurso no se niega la condición miserable en la que caen muchos seres humanos, es más, se reconoce que la mísera condición humana existe y es real; no obstante, suele ser el producto de un actuar moral envilecido y despreciable. En el Discurso no se defienden propensiones favorables y exageradas sobre la realidad y la existencia humana, por las que las cosas mejorarían casi por un supuesto progreso espontáneo y propio de la humanidad. Lo que realmente hace el Discurso es un reclamo imperioso, acuciante y necesario para dirigir nuestros actos hacia la integridad y decencia moral: «(...) en definitiva, se propone -envuelto en el brillante lenguaje renacentista- una estructura dramática de la existencia humana» (García 2013, páginas 64 y 65)
Casi cien años después aparecerá la obra $E l$ criticón, que se publicó en tres partes -en el año 1651,1653 y 1657-, y que es del autor español Baltasar Gracián. Esta obra también tratará sobre la dignidad humana, refiriéndose al ser del ser humano y a los medios necesarios para lograr ser persona a través del ingenio y la agudeza propios del ser humano. En $E l$ criticón, se propone un panorama humano de la inmortalidad, siguiendo la perspectiva del humanismo, en tanto naturaleza y dignidad del ser humano. Lleva pues una influencia fuerte del humanismo renacentista sobre todo en relación a la alabanza del ser humano. El ser humano es concebido como imagen y reflejo del universo, considerándolo, aunque de tamaño reducido, en un mundo del arte y de la moral. En esta obra de Gracián, el sabio es considerado como alguien que se acerca a Dios ya que es el propalador de los saberes, a diferencia del populacho ignorante que es manejado por sus instintos; se ataca, en definitiva, a la ignorancia $\mathrm{y}$ al fraude de los saberes. $\mathrm{Y}$ es que, en el Renacimiento, la dignidad humana se relacionaba con el conseguir de los saberes desde un panorama secularizado que es en el que se desarrolla la obra de Gracián; los valores morales, políticos y sociales son los que nos apartarían de la condición de los meros animales. El criticón representa una reflexión filosófica sobre la vida y, más específicamente, sobre la vida humana; toma la idea de la virtud y el triunfo sobre las miserias humanas como el camino al logro de la verdadera dignidad, lo que nos llevaría hacia la cualidad divina de la inmortalidad. La sensatez para llegar a tener un determinado criterio sobre la realidad humana, es un tema de crucial importancia para la dignidad humana en la obra de Gracián:

(...) sabed que al hombre (...) como rey que es pretende señorearlo todo. Pero entiende, ¡oh hombre! (...) que esto ha de ser con la mente, no con el vientre, como persona, no como bestia. Señor has de ser de todas las cosas criadas, pero no esclavo de ellas: que te sigan, no te arrastren. (Gracián 2007, página 73 )

El ser humano, en la obra de Gracián, caería en la miseria cuando se obstina a su parte animal. El saber es el modo en que el ser humano consigue las mejores posibilidades de ser tal, fundiendo sus teorías y saberes, con la práctica de su actuar. La sapiencia es el camino correcto para descubrir y obtener el mayor y 
más elevado destino. Es la razón, además de la palabra por la que se adquieren las letras y las artes, lo que coloca al ser humano en una situación y en un nivel mayor que el del resto de animales. Esto nos hace seres que, ejerciendo nuestra libertad, podemos dominar nuestro entorno y nuestra realidad; el ser humano, en la filosofía graciana, supera a las bestias gracias a la razón y al lenguaje. Las miserias nos persiguen constantemente como parte de nosotros mismos, y son las letras las que nos libran de ellas; sin embargo, las letras no sirven de nada si es que los seres humanos no ponen en permanente práctica el ejercicio de un diligente y esmerado uso de la razón y de la moral en las acciones que realice. Baltasar Gracián desenvuelve su citada obra, planteando una dualidad entre miseria y dignidad, que maniataría o liberaría al ser humano, según se deje llevar por sus instintos y lo acerque a la condición de animal, o según domine dichos instintos mediante la razón y se acerque a un estado de divinidad que sobrepase su naturaleza humana. La ignorancia del ser humano es un mal porque implica que este no emplea correctamente sus potencias y sentidos. La vida, para Gracián, es una ruta rumbo a la eternidad. El criticón es un recorrido por la realidad del mundo en donde se le da vida a la argumentación entre dignidad y miseria, que representaría la dupla condición natural del ser humano y de la realidad del mundo, con sus prodigios y desgracias. Para Baltasar Gracián, no se puede emancipar, en la realidad humana, la dignidad de la miseria humana; el ser humano, por ser tal, está conformado por las dos, cual cuerpo y alma. Cada una -miseria y dignidad- se expresarán, en la realidad de cada quien, según las coyunturas y según el talante moral que se asuma. Si la postura moral es correcta, la dignidad humana triunfará y se sobrepondrá a las miserias humanas, pudiendo pronosticarse la inmortalidad de quien las derrota. El ser humano ante las miserias, propias y ajenas, que le afectan, él puede superarlas con su esmero acercándose así a lo divino. Sin embargo, para Gracián, la sapiencia no otorga la felicidad. Es la fama póstuma en la memoria de los demás lo que proporcionaría el mayor acercamiento a la felicidad. La forma de acercarse a la felicidad -aunque esta sea imposible de alcanzar- es fijándose objetivos reales; en El criticón se habla de la inmortalidad como objetivo a alcanzar. En esta obra, Gracián sostendrá que no habrá elevación ni grandeza de nuestro ser, sin que se nos presenten miserias en la vida, ni tampoco habrá dignidad que podamos alcanzar si no superamos antes dichas miserias. En definitiva, El criticón, de Baltasar Gracián, resume la vida práctica del ser humano quien se desenvolvería en una suerte de tragicomedia, cuyo desenlace supondría la felicidad y el alcance de la dignidad, luego de superar, en última instancia, toda una serie de tragedias que su propia vida le impone; luego, serán la fama, surgida por la actitud heroica de dominar los vicios e instintos de nuestra naturaleza, los que nos proporcionarán la inmortalidad que es el nivel más elevado donde se ve reflejada la dignidad, y que es, según Gracián, el inmejorable modo de huir a la miseria de la inevitable muerte. Si bien es cierto, el ser humano pasa por una serie de vicisitudes, infortunios y desdichas, todas estas tragedias de su vida le posibilitan el fortalecer y asegurar la dignidad de su propio ser, siempre que se manejen con virtud y con valor en sus acciones para vencer lo lascivo y salvaje de los apetitos de su ser natural. Aquí está el nivel más alto de la dignidad que Gracián propone; es decir, desde que el ser humano logra rebasar y sobreponerse a la tragedia de las miserias de su existencia, usando sus saberes y virtudes que les son propias, en tanto ser humano que es. Gracián, no se situó en el plano del cumplimento teleológico para lograr la inmortalidad; la trascendencia humana se situaría en la memoria de los demás, lograda con la virtud del valor y con el de la reputación. En El criticón, se resalta la inmortalidad de la memoria eterna por encima de la salvación del alma. Finalmente, advertiremos que Baltasar Gracián, evidencia la lucha interna que tenemos los seres humanos, donde debemos ser capaces de vencer, durante toda nuestra vida, todo aquello que nos acerca a la mera condición de animales dominados por nuestros apetitos. Somos capaces de subyugar a nuestras miserias e infortunios gracias a la dignidad que alcanzamos comportándonos con esmero, saber y control en todas nuestras acciones.

Si seguimos avanzando en el tiempo, nos vamos a encontrar con otro autor que suele ser al que regularmente la doctrina se refiere a la hora de hablar de la dignidad humana. Este autor es Inmanuel Kant. Este tema va a estar tratado sobre todo en sus obras de filosofía práctica o de ética, como lo son la Fundamentación de la metafisica de las costumbres (1785) o la Crítica de la razón práctica (1788). Kant 
a partir de su estudio de la realidad y desde su planteamiento de ética formal y universal, busca sustentar cómo es que la dignidad humana es una aptitud y un atributo propio de la humanidad, y que no poseen los otros seres animales ni todo aquello que el ser humano cree con su talento y perspicacia. Kant sostiene que el ser humano es un ser de fines, apto para decidir fines y para discernir la orientación de sus objetivos. Kant también sostiene que el ser humano es un ser apto para vivir una experiencia que le es exclusiva. En su obra Crítica de la razón práctica, Kant nos habla de dos cosas que llenan nuestra resolución y nuestra energía con un deslumbramiento y una devoción, restauradas y ascendentes. Estas dos cosas son el cielo estrellado sobre mí y la ley moral dentro de mí. Estas dos cosas que colman mi ánimo humano, las veo ante mí y las asocio de inmediato con la conciencia de mi existir. El cielo estrellado sobre mí me hace tener conciencia del lugar que tengo en el mundo exterior de los sentidos y extiende la relación que me sitúa en una ilimitada amplitud de mundos, metamundos y sistemas de sistemas. La ley moral dentro de mí es la que se origina desde mi inherente yo invisible, desde mi genio, identidad y carácter; es la que me representa en el mundo infinito, pero que únicamente es apreciable por el entendimiento. Con este último me reconozco como un ser vinculado, pero no como algo fortuito, casual o aleatorio, sino con una conexión universal y necesaria. Es decir, podemos entender que, en Kant, la experiencia de la ley moral dentro de mí es la que me impone que al otro lo trate siempre como un fin y no como un mero medio o instrumento. Esta práctica es ciertamente humana y es la que nos coloca como seres con atributos y cualificaciones distintas al resto del todo de la naturaleza. Claro está, que, entonces en Kant, el ser humano es quien decide si vive de acuerdo a esa ley moral, o si sea capaz de explorarla. Con lo cual, el ser humano también podría decidir torcerse y abandonarse al estado inferior propio de su humanidad. En todo caso, lo rescatable de la idea de Kant es que el ser humano tiene la capacidad en su misma naturaleza, lo que lo hace atributiva y extraordinariamente diferente al resto de seres de la naturaleza, y aquí radicaría parte del sustento de su dignidad. Para Kant, el cielo estrellado sobre mí de una infinidad de mundos, suprime mi importancia como criatura animal; en cambio la ley moral dentro de mí:

\begin{abstract}
(...) eleva mi valor en cuanto persona infinitamente, gracias a mi personalidad, en donde la ley moral me revela una vida independiente de la animalidad e incluso del mundo sensible en su conjunto, al menos por cuanto cabe inferir del destino teleológico de mi existencia merced a esta ley, la cual no se circunscribe a las condiciones y los límites de esta vida, sino que se dirige hacia lo infinito. (Kant 2018, página 250)
\end{abstract}

En el tema de la dignidad también nos vamos a encontrar con Johann Gottlieb Fichte que es un filósofo idealista alemán para quien la dignidad se corresponde con la libertad potencial del ser humano de poder conformar determinaciones libres, de pensar por sí mismo, de no estar definidos por lo preceptivo de la especie o por las exigencias rigurosamente naturales. El ser humano es capaz de controlar las exigencias naturales y determinarse con ellas, sobre ellas o en contra de ellas, en su plan de vida: El ser humano en tanto en que es libre, o sea: «(...) en la medida en que es sujeto absoluto y no representado ni representable, no tiene nada en común con los seres de la naturaleza y, por tanto, tampoco es opuesto a ellos» (Fichte 2015 trad. por Cruz, página 38). La vida transcurriría con las mismas leyes, y todas las épocas y tiempos serían iguales si es que el entendimiento no las impregnara con el intelecto; de no ser así la vida del ser humano solo sería una vida animal o vegetal:

El dejar pasar desapercibidamente todo lo que acontece, cerrando (...) ojos y oídos contra su embate, el vanagloriarse de esta irreflexión incluso como si fuera mayor sabiduría, puede ser admisible para una roca (...) o a un tronco de árbol (...), pero de ningún modo para un ser racional. (...) el enemigo de nuestra autonomía (...) Si está seguro de que no reflexionamos nada sobre ninguna materia, puede hacer con nosotros lo que quiera (...); la irreflexión es precisamente lo que se acostumbra a todo, pero donde el pensamiento claro y amplio y en él la imagen de lo que debería ser permanece alerta, allí no echa raíces el hábito. (Fichte 2015, página 373)

Para Fichte, el yo es genuinamente el génesis de todo; el yo no es un simple espectador de lo que hay fuera de él -es decir, el no-yosino que es el protagonista de esa realidad 
externa. Este protagonismo es lo que dignifica al ser humano. El caer en la pasividad o el dejarse simplemente llevar por todo lo que hay, enturbia nuestra dignidad, nos convierte en cosas meramente naturales, en el no-yo, e implica el rechazo de nuestro destino. Al ser sujetos vinculados por nuestra humanidad, la dignidad solo la podemos desarrollar en nuestras relaciones con los demás seres humanos. El ser humano logra su libertad, en una comunidad, cuando está con otros seres humanos también libres y, con ello, sabe que debe restringir su libertad en el momento que identifica la libertad de los demás: «El hombre debe cada vez más acercarse indefinidamente a la libertad, en sí misma inalcanzable» (Fichte 2015, página 38). Para poder ejercer la propia libertad, cada sujeto debe saber coartar su libertad para que así todos puedan ejercer esta libertad de la misma manera; debo respetar en mi accionar la libertad de los demás seres ajenos a mí; no se trata de qué deben hacer los demás de acuerdo a lo que yo considere; lo que interesa es saber qué me está autorizado hacer a mí para estimular y persuadir a los demás a que hagan lo que yo considero correcto. Debo, por supuesto, respetar sus convicciones, sus voluntades y su consentimiento, comprobando que el ordenamiento social lo permita. Los demás actúan libremente según su voluntad y bajo su propia responsabilidad, y no soy quién para permitirme modificarlo: «Me importa más respetar su libertad, que impedir o suprimir lo que me parece malo en el uso que hacen de ella» (Fichte 2011, página 195). Entonces, resulta que la dignidad, Fichte la entiende como una institución de orden y relación (Torralba 2017, página 78). Fichte nos invita a fundar los juicios finales de nuestra razón, en la necesidad y creencia de la idea que él sostiene cuando dice que:

(...) la humanidad irá mejorando siempre que las ideas de un orden y de una dignidad de la mimas no son sueños vacíos, sino el presagio y la prenda de la realidad futura (...). (Fichte 2015, página 411)

Dejando a Fichte, voy a incursionar en otro autor. Friederich Schiller, es un autor que se preocupó mucho por la reflexión sobre la dignidad y es a él al que me referiré ahora. Schiller es un personaje que defiende el anhelo de un mundo mejor y más hermoso. La obra que hay que tener en cuenta para este tema va a ser, De la gracia y de la dignidad. En ella, lo que hace Schiller es desarrollar su concepto de belleza en lo que es el personaje humano. Schiller se va a referir al alma bella, la que para él es el alma que cumple su deber con voluntaria naturalidad, impulsada por la belleza; con lo cual, se trata de la belleza que se alcanza por la gracia natural y armónica entre el instinto y la ley moral. Esta situación se debería, espiritualmente, al amor por la libertad. La libertad verdadera sería la que se sitúa en la conciencia de cada ser humano. En el momento que la razón y la moralidad entonan entre ellas, cuando el deber y la inclinación están armonizados, recién allí existe la posibilidad de una belleza real. Entonces, recién la belleza surgirá reflejada en la dignidad, al situarse esta última como el carácter dominante, además de surgir también del reflejo de la sensibilidad como manifestación del impulso instintivo dominante. La dignidad se enmarcaría en la fuerza moral que tienen los seres humanos de controlar sus impulsos instintivos para así poder alzarse espiritualmente. Para Schiller el ser humano es capaz de comportarse libremente sin sucumbir a dejarse dominar por el mundo de las necesidades. El ser humano tendría un rol protagónico y determinante sobre su propio destino y sería el único ser capaz de controlar y regular sus necesidades, lo que lo coloca en la situación de ser un agente capaz de forjar desde sí mismo todo un conglomerado innovador de realidades. Esta capacidad de autocontrol proporciona al ser humano una preeminencia sobre los demás seres, dotándolo así de dignidad. La dignidad se determinaría en el control de los comportamientos impulsivos e involuntarios y en la capacidad de vencer a la naturaleza; la dignidad es la revelación de un talante y una energía excelsa. La dignidad aviva la sensación de respeto, de consideración y tolerancia hacia los demás, evitando que el amor termine corrompiéndose y acabe convertido en el vicio del deseo. Libertad para Schiller es la facultad que se tiene para poder librarse de los obstáculos existentes en la naturaleza humana; no se trata meramente de poder elegir entre varias opciones cualesquiera que sean estas; se trata de contar con la oportunidad de poder elegir el derrotar a los instintos propios de nuestra humanidad natural. La dignidad es la libertad del espíritu de poder optar por dominar los instintos humanos. Finalmente, en Shiller, la dignidad no es inherente a todo ser humano en cuanto tal referido es propio de su ser natural; la dignidad 
se domina y se consigue con las decisiones que ejerza en mi propio accionar, con lo cual, la dignidad estaría sometida al merecimiento que mi comportamiento determine:

El dominio de los instintos mediante la fuerza moral es la libertad del espíritu y la expresión de la libertad del espíritu es el fenómeno que se llama dignidad. En el animal y en la planta la naturaleza no sólo fija el destino, sino que, además, lo ejecuta ella sola. Pero al hombre no hace sino señalarle su destino y le confía a él mismo su cumplimiento. (...) la gracia es la expresión de un alma bella, la dignidad lo es de un carácter sublime. (...) La dignidad surge por sí misma en la virtud, ya que por su contenido presupone el dominio del hombre sobre los instintos (...) es expresión de la resistencia que el espíritu autónomo ofrece al instinto natural. (Schiller 1962, páginas 45-75)

Situándome en un autor más actual que trata sobre la dignidad humana, me referiré a Peter Sloterdijk. Para este autor la dignidad humana está puesta en peligro por los medios de comunicación social que idiotizan al ser humano y está puesta también en peligro por la falta de capacidad que tienen los maestros, los sabios y los educadores, de domesticar al ser humano. Para Sloterdijk el ser humano es el rey de los animales domésticos y es, a partir de sus niveles más básicos, una criatura cultural. La cultura, toda ella, será como una gran incubadora que cubre a los sujetos. El ser humano depende siempre de una conducción cultural. Sloterdijk dice que los psicólogos ya advierten de los peligros que provoca el debilitamiento de los símbolos de autoridad en la sociedad posmoderna que va quedando, dice, huérfana de padre:

(...) la domesticidad sigue incompleta porque a menudo las culturas concretas no se colocan bajo un techo común, sino que constituyen entornos mutuamente extraños, y no pocas veces enemigos. (...) la falta de domesticidad arroja sus sombras sobre las relaciones internas de las culturas. (Sloterdijk 2018, página 36)

Si ahora nos fijamos en lo que sostiene Jürgen Habermas, veremos que este autor va a defender que es la comunidad de diálogo la llamada a juzgar el valor o la dignidad que tienen los animales, las plantas y los humanos, como tales. Para Habermas, la dignidad es un valor que se asigna por razones específicas y no por una suerte de inherencia propia del ser. Sin embargo, este autor, entiende que no hay una posición única y unificada sobre lo que es la dignidad humana, aunque para él, en términos generales, la vida humana, en sí misma, amerita respeto y es merecedora de dignidad, incluso desde su estado emergente, es decir, desde la vida embrionaria. Para Habermas la vida está ya adjudicada de dignidad, aunque el acepta que, filosóficamente, sea muy intrincado el defender que una vida humana emergente se deba equiparar con la vida de un interlocutor en la comunidad de diálogo; sin embargo, si bien, esa vida embrionaria no es un interlocutor válido, en democracia hay que tenerle también consideración y respeto. La dignidad es un término que hace referencia a una dilatada gama de significados $\mathrm{y}$, la dignidad humana, propiamente dicha, es una resonancia o extensión que constituye uno de los significados de la expresión dignidad. Habermas relaciona el término dignidad con el honor y explica que el concepto de honor se origina con mayor claridad, históricamente, en los usos que se hacía de este en la época anterior a la modernidad. Esto, de alguna forma marcó un antecedente en el significado de dignidad, en cuanto a la forma de vida de esos tiempos que dependía mucho del estatus social que cada uno tenía:

La dignidad del rey se encarnaba en un estilo de pensar y actuar diferente al de la mujer casada, el soltero, el artesano y el carnicero. De estas acepciones concretas de una dignidad determinada en cada caso se abstrae la dignidad humana universalizada que corresponde a la persona como tal. (Habermas 2018, página 55)

Entonces, en general, puedo decir que el concepto de dignidad ha recorrido un trayecto evolutivo que se puede distinguir desde la época de la Roma antigua. En esa época, la dignitas definía a la personalidad y al posicionamiento representativo que poseía una persona en la vida pública. Por esta posición social y representativa, los que ejercían cargos en el Estado y los políticos gozaban de un prestigio y de un renombre que cimentaban su dignidad. Luego, más tarde, esta situación que privilegiaba a una persona en razón de su posición políticosocial, con la teología medioeval, pasó a 
generalizarse, entendiéndose que la dignidad les correspondía a todos los seres humanos en virtud de la situación que guardaba en el mandamiento divino. Así, entendiéndosele como hecho a imagen y semejanza de Dios, el ser humano pasó a tener una dignidad propia, particular y distinta a la de los demás seres vivos, aceptándose que todos los seres humanos poseen la prerrogativa de ser parte de los propósitos de Dios. En el Renacimiento $\mathrm{y}$, luego, con la Ilustración, la definición de dignidad, según se había generalizado a todos los seres humanos, mantuvo su concepto e idea universal, pero pasó a defenderse desde una argumentación secularizada en donde los propósitos teológicos que fundamentaban a la dignidad, fueron dejados de lado. A partir de este momento, al ser humano se le reconoce como alguien con razón y capaz autodeterminarse, lo que por sí mismo lo hace ya un ser digno sin necesidad de sustentar esa, su dignidad propia, en fundamentaciones de índole teológico.

\section{LA DIGNIDAD Y LAS NORMAS DE DERECHOS HUMANOS}

Las normas de derechos humanos son aquellas con las que se pretende sostener, normativamente $y$ en última instancia, la promoción, defensa y protección de la dignidad humana. Los derechos humanos, son instrumentos o medios para la consecución de dicho fin, entendiéndose que una vida plena es aquella que se desarrolla en el respeto de todos los seres humanos, en tanto todos, como personas, somos seres merecedores de una misma dignidad.

En términos generales, se puede decir que los derechos humanos, formalmente normativizados, son una de las más grandes victorias frente al poder imperante de una sociedad. La dignidad humana, como hemos visto, se puede enmarcar desde diferentes conceptualizaciones filosóficas y doctrinarias, aunque todas ellas, redundan siempre en su afán de reconocer la importancia del ser humano; sin embargo, siempre puede existir, filosófica y doctrinariamente, cierto grado de distinta interpretación $\mathrm{y}$, muchas veces, de antojada y oportunista interpretación, con el único fin de favorecer intereses particularistas que no siempre les ocupa el respetar la dignidad y del derecho de los demás. Por ello, el incorporar los derechos humanos y la idea de dignidad humana, dentro del derecho normativo, hace que una interpretación oportunista y desfasada, tenga menor posibilidad de imponerse. Claro está, que el poder siempre intentará usar la dignidad y los derechos, incluso los normados formalmente, para interpretar lo que mejor le convenga a sus intereses. Por ello, la importancia de que las normas sean claras, sin vacíos y libres de antinomias. Y teniendo en cuenta que los derechos humanos tienen una vocación de universalidad, es también importante que exista cierto nivel de consenso y uniformidad en lo que respecta al concepto de lo que son los derechos humanos y la dignidad humana que ellos buscan promover y proteger.

Históricamente nos podemos referir al Bill of right de Inglaterra, que deificaba la "Gloriosa Revolución» de 1689, y a los Bills of rights de las colonias americanas sublevadas, en 1776 , en contra del sometimiento inglés en el que se encontraban subyugadas. Luego, nos encontramos con la Declaración de los derechos del hombre y del ciudadano, ocurrida en Francia, el año de 1789. Aquí se declaraba la igualdad y la libertad de derechos de todos (aunque se refería a los hombres, que además debían de ser ciudadanos, blancos $\mathrm{y}$ propietarios), asimismo, se proclamaban sus derechos naturales e imprescriptibles -la resistencia a la opresión, la propiedad, la libertad, la seguridad-, y en base todo esto, se erigiría una legítima asociación política.

La Declaración francesa se aleja del Bill of rigth inglés, por cuanto en este no se produce el reconocimiento a los derechos del hombre $\mathrm{y}$, más bien, se ratifican los derechos tradicionales y consuetudinarios del ciudadano inglés sustentados en el common law. A diferencia de lo anterior, conceptualmente, los Bills americanos y la Declaración francesa sí se asemejan mucho, en tanto ambas están infundidas por el iusnaturalismo y por el contractualismo, que eran las ideas imperantes de su época; los hombres tendrán derechos naturales que son previos al establecimiento de las sociedades; y, a estos derechos, el Estado tiene la responsabilidad de aceptarlos, admitirlos, protegerlos y respaldarlos, como derechos ciudadanos.

Ahora bien, en el ámbito internacional, se van a suscitar sendos intentos por parte de los Estados, sobre todo luego de los acaecidos 
hechos de la II Guerra Mundial, con lo que se pretendía dar real promoción y protección a los derechos y a la dignidad de las personas. Se buscaba que la acción política tenga un rol verdaderamente protagónico en la defensa del respeto al ser humano. En un principio, el mayor asunto a superar fue el celo que los Estados tenían para la defensa de su soberanía nacional haciendo que a muchos les costara aceptar la injerencia internacional en la manera interna en que cada Estado trataba sus asuntos referidos a los derechos humanos. Conocidos los horrores cometidos por los alemanes del nazismo, recién se entendió la necesidad de que exista un orden internacional en materia de derechos humanos en aras de alcanzar una real protección de la dignidad humana que no permita que vuelvan a ocurrir semejantes perversiones en la historia de la humanidad. Así, se impulsó una estrecha cooperación y solidaridad internacional para poner en valor y a buen recaudo la condición humana en cuanto tal. Las Naciones Unidas juegan un papel importante en toda esta etapa y el 10 de diciembre de 1948 la Asamblea General abrazó la Declaración Universal de Derechos Humanos. Es importante advertir que, antes, en la Carta de las Naciones Unidas del 26 de junio de 1945, en su preámbulo, se decía que dicha Carta buscaba proteger a la generaciones próximas para que no se vean otra vez afectadas por el flagelo de la guerra que dos veces infligió a la Humanidad «sufrimiento indecibles), y, luego, en 1948, en el preámbulo de la Declaración Universal, se acusa de manera más amplia y profunda diciendo que son el desconocimiento y el menosprecio de los derechos humanos, los que habrían generado actos de barbarie ultrajantes para la conciencia de la humanidad. Lo primero parece circunscribirse al hecho concreto de los sufrimientos que provocaron las guerras mundiales $\mathrm{y}$, lo segundo, ya entra a hablar sobre el amplio daño que se ha provocado y que afecta a la conciencia de todos -es decir de toda la humanidadcuando permitimos el desconocimiento y el menosprecio a los derechos humanos. En estos dos documentos se refleja que, tanto la Carta como la Declaración, son la contestación que se hizo al desastre político y moral, en el que cayó nuestra humanidad.

Ahora bien, es relevante referir que la Declaración Universal se adoptó no sin dificultad, ya que era muy complicado lograr que los Estados acepten responsabilidades jurídicas específicas que los supediten de forma categórica e incuestionable. Aquí, el gran problema era consensuar enunciados idóneos que puedan reflejar y unificar los arquetipos y ambiciones coincidentes de los Estados en cuanto al respeto de la dignidad humana y, con ello, a la promoción y protección de los derechos humanos. Era una tarea difícil puesto que los Estados miembros respondían a prácticas y acervos distintos, tanto en el ámbito jurídico, como en el político y religioso. Conciliar estas diferentes prácticas y acervos, fue toda una tarea titánica. En este escenario de diferencias, también había que tener en cuenta la situación social y económica de cada Estado. Ello era más notorio a la hora de intentar acuerdos para los llamados derechos económicos, sociales y culturales. Para un país económicamente desarrolla, le será menos problemático aceptar y cumplir con dar satisfacción al derecho a la educación o al derecho a la salud pública, porque, por lo general, estos países ya cuentan con toda la infraestructura necesaria para ello $\mathrm{o}$, en su defecto, siempre pueden gestionar y costear su creación y puesta en funcionamiento; para los países decaídos económicamente, los derechos sociales y culturales, no resultaban ni resultan de fácil cumplimiento. En el año 1966 se adoptaron en Naciones Unidas, dos pactos internacionales de gran importancia y que hasta el día de hoy siguen vigentes. Lo curioso, es que, pese a ser pactos importantes porque buscan sostener el respeto a los derechos de las personas a fin de asegurarles el desarrollo de su vida en dignidad, estos pactos tardaron en entrar en vigor casi diez años (en el año 1976), y esto debido a la demora y reticencia de muchos Estados para ratificarlos. Y es que se acordó en la norma de estos mismos pactos -en aras de poder hablar de un cierto consenso mínimoque ellos entrarían en vigor recién pasados tres meses y luego de alcanzar el depósito de las treinta y cinco ratificaciones, situación, claro, que fue muy difícil de lograr y, por ello, su gran demora para la vigencia. Esto revela una cierta e importante indecisión o indefinición sobre la actitud firme con la que debieran contar los Estados a la hora de asegurar la eficiencia real de la dignidad humana y de la protección de los derechos que ella conlleva.

Como decía antes, en el año 1966, en Naciones Unidas, se adoptaron dos pactos internacionales. Estos son, por un lado, el Pacto sobre los derechos económicos, sociales y culturales y, por otro lado, el Pacto de derechos civiles y 
políticos. El pacto de derechos económicos, sociales y culturales, contiene disposiciones programáticas destinadas a lograr levantar y quitar los obstáculos que existen a estos derechos, requiriéndose, en este pacto, el uso de los mayores recursos del que disponga cada Estado para ello. Aquí, principalmente se trata de una gestión que supone el ejercicio de una gestión de hacer por parte de los Estados; nos encontramos aquí con el derecho a la asistencia, el derecho al trabajo, al estudio, a la salud, a la vivienda, etcétera. Todos estos derechos son, en cierta forma, consecuencias de las exigencias surgidas de la industrialización de las sociedades y que conllevó a la gestión activa por parte de los Estados, donde ellos se ven obligados a garantizar activamente este tipo de derechos asistenciales, a fin de que el nuevo sistema social industrializado funcione certera y correctamente. En cambio, en el pacto referido a los derechos civiles y políticos, se contienen disposiciones que, principalmente, son mandatos, órdenes, instrucciones y reglas, que tratan sobre derechos y libertades, y que cuya garantía consiste, usualmente, en un no hacer de los Estados. Los derechos civiles tratan sobre la personalidad del individuo en tanto a su libertad personal, de religión, de pensamiento, de reunión, etcétera; estos derechos los puede ejercer libremente cualquier persona siempre que no afecte el también legítimo derecho de los demás. El Estado aquí asume un compromiso de no impedimento. Los derechos políticos se refieren a la libertad de asociación en los partidos y a los derechos electorales; estos se relacionan con la formación de la democracia representativa, y supone la libertad y participación activa de los ciudadanos en la política, participación que los Estados no deben impedir ni hacer gestión alguna para que la obstaculice.

Por su parte, la Declaración Universal de los Derechos Humanos, no es un documento que pretenda retomar y enarbolar nuevamente los argumentos del derecho natural de las declaraciones de derechos humanos del otrora. En la Declaración Universal se habla ya específicamente de la dignidad humana, y aunque en sí no la define, sí la sitúa como una institución que se debe promover y proteger mediante el respeto de todos los demás derechos que se regulan en dicho documento internacional. La dignidad humana no aparece en las declaraciones del siglo XVIII. La dignidad humana, normativamente, va a surgir expresamente mencionada, luego de la II Guerra Mundial, como idea universal a defender en contra de los totalitarismos y sus actos de barbarie ultrajantes. Por ello, en el preámbulo de la Declaración Universal de 1948 se reconocerá que la dignidad humana es intrínseca a los miembros de la familia humana y que sus derechos le son iguales e inalienables a todos. Luego, refuerza esta idea en su artículo primero, cuando dice que <Todos los seres humanos nacen libres e iguales en dignidad y derecho. Vemos como la dignidad humana se empieza a instaurar como un elemento fundamental alrededor del cual se articulan los derechos humanos. Meses más tarde, en mayo de 1949, se promulgó la Ley Fundamental de Bonn (o Constitución de la República Federal Alemana) y, en ella, se afirma que la dignidad humana es un fundamento intangible; esto es lo que se lee en el primer artículo de esta norma: La dignidad humana es intangible. Respetarla y protegerla es obligación de todo poder público. Este uso de la institución dignidad humana, se hace con el fin de proporcionar un eje común y universal que pueda dar sustento a un régimen internacional de los derechos humanos. Se trata de lograr un eje en el que exista una importante coincidencia por parte de los Estados, a fin de poder instrumentalizar en consenso aquello que se puede llamar como el derecho internacional de los derechos humanos. Sin embargo, como veíamos antes, frente a la falta de definición normativa de lo que es la dignidad humana en sí misma como concepto, y frente a la diversidad de definiciones y usos que se hacen de ella, tanto en el ámbito filosófico como político, resulta que la dignidad humana, como institución, no logra alcanzar la relevancia y el reconocimiento que pretendey, más bien, parece estar trivializándose y yendo hacia un estado de vacuidad que la condena a la irrelevancia y a la pérdida total de su protagonismo en materia de derechos. Formal, normativa y declarativamente, a la dignidad humana, se le suele dar y reconocer la importancia que tiene; el problema surge cuando hay que resolver en la realidad práctica, en consonancia con esta importancia declarada, los asuntos propios de la humanidad (los asuntos económicos, políticos, de Estado, etcétera). En este último orden, las declaraciones y reconocimientos formales de importancia, no se ven reflejados en la práctica social. La eficiencia práctica ya es un asunto que se encuentra obstaculizado por otros intereses o por la ambigüedad en la que 
se cae, o se finge caer, sobre el entendimiento de lo que es la dignidad humana y su mayor relevancia y preferencia social. Esto da pie a que se hagan y se fuercen interpretaciones de todo tipo, con las que se deja de atender a los derechos humanos y a la dignidad humana, $\mathrm{o}$, simplemente, se les termina colocando en una posición secundaria o peor, para dar preferencia y cabida a otros intereses a los que no les preocupa las declaraciones formales que se pueden saltar impunemente, incluso legalmente y con el apoyo de gobiernos de turno y de poderes de imperantes. Por ello, declarar que la dignidad humana es intangible -es decir, que no puede ser tocada bajo ninguna situación-, declarar o que la dignidad humana le es intrínseca a todo ser humano, son declaraciones, que, si no logran eficiencia en la realidad social, sirven y valen de poco o nada para el desenvolvimiento de nuestras vidas, que es lo que realmente importa y preocupa a La familia humana. En este sentido, sin negar la necesidad de apoyarse en la "Fe de Dios" para lograr no perder el camino de la rectitud y respeto para nuestras vidas y para la de los demás, también es cierto que es importante que aquello que se pregone y declare de manera formal, deba resultar eficiente en la práctica social y que los ciudadanos lo adviertan así, precisamente para dar legitimidad y fuerza las normas que protegen la dignidad humana y a los derechos humanos. Una norma que se percibe y se nota como ineficiente e inservible, termina perdiendo el respeto y se deja de cumplir. Aquí una de las líneas de explicación que exponen los filósofos Christoph Menke y Arnd Pollmann me parece de especial pertinencia en esta parte: «(...) una fundamentación plausible de la idea de dignidad humana debe poder lograrse si es que quiere ser convincente en un mundo moderno y pluralista» (Menke y Pollman 2010, página 147). Y a esto yo agregaría, que no hay mejor fundamentación más plausible, que el logro eficiente en la realidad de aquello que se defiende como dignidad humana intrínseca, inalienable e intangible.

Lo que es evidente, es que, cuando hablo de los entresijos de la dignidad humana, esto se manifiesta bien cuando vemos que lo que se suponía que era claro para todos, resulta que al momento de tener que resolverse en favor de esa claridad -comprometiéndose y obligándosedicha situación ya no es tan clara y, más bien, parece de lo más intrincada y difícil de asumir y resolver, sobre todo a consecuencia de los propios intereses que, demasiadas veces, no son más que intereses particularistas que se mantienen ocultos tras la mascará formal de la asunción de pactos, convenios y declaraciones internacionales.

Lo cierto es que, la dignidad humana $\mathrm{y}$ los derechos que le son propios para su consecución, no pueden quedar como simples principios formales o programáticos que no encuentran eficiencia práctica en la realidad social en la que se desenvuelven. La dignidad humana tiene que concretarse en la realidad de la vida de cada individuo y no quedarse en la mera abstracción normativa y formal de las Constituciones, convenios, pactos y declaraciones que digan protegerla.

Entonces, ¿cómo se logra que los Estados cumplan sus compromisos de respeto a los derechos humanos y, con ello, a la dignidad humana? Lo cierto es que no existe un órgano internacional que pueda obligar a los Estados a garantizar el cumplimiento de sus compromisos. Esta situación se subsana con el interés que cada uno de los Estados miembros tiene de respetar y cumplir sus compromisos para evitar la reacción o la toma de medidas que los otros Estados partes puedan gestionar en su contra -como sanciones económicas, por ejemplo- a fin de que el Estado infractor cumpla o corrija su accionar. Se puede decir, que a los Estados partes les interesa mantener buenas relaciones entre ellos, en procura de su propio bienestar particular; de esta forma, la imagen internacional que se tenga ante los demás es crucial para las buenas relaciones de cooperación, intercambio y de transacción de todo tipo, entre los Estados. Esto deja entrever, que más que un compromiso y una convicción real, lo que mueve a los Estados son intereses sustancialmente alejados y subalternos a los derechos humanos y a la misma dignidad humana. Sin embargo, si tenemos en cuenta que realmente los Estados no surgen por generación espontánea ni tienen una existencia propia o abstracta, y distinta a la humanidad, puedo afirmar que los Estados surgen y se concretan en los mismos seres humanos. Somos los seres humanos los que constituimos los Estados y somos nosotros los que decidimos su comportamiento en uno $\mathrm{u}$ otro sentido. $\mathrm{Y}$ para ser más específico, son los poderes y aquellos que gobiernan las sociedades los que determinan el buen hacer o no de los Estados en materia de derechos 
humanos y de respeto a la dignidad de todos. Con lo cual, el actual y verdadero problema radica en que hay ciertos grupos de poder $\mathrm{y}$, con ello, ciertas personas, que caen en un estado de inconsciencia que les hace creer que lo único que importa y que les importa es el sostenimiento de su propia dignidad, de su propio bienestar y de sus propios derechos. La dignidad, el bienestar y los derechos de los otros, son algo que les es ajeno y que solo les preocupa en tanto no les afecte los privilegios de poder y de mejor bienestar de los que gozan. Si gobiernan es para prometer de todo en campaña electoral, pero luego, si llegan al poder, ya cumplir lo prometido es cosa distinta y según conveniencia e interés de mantenerse en el poder conseguido. Si no gobiernan y son grupos de poder económico o de otra índole, de lo que se trata es de privilegiar a los integrantes de sus grupos en aras de preservar el mismo o, incluso, engrandecerlo y potenciarlo.

Es paradójico, además de lamentable, que quienes nos gobiernan terminen pervirtiendo su función, olvidando que ellos están para moderar y contener los desvíos y degeneraciones en los que puedan caer los miembros de la sociedad; ellos -los que gobiernan- están para corregir las perversiones, no para pervertirse igual o peor que los ciudadanos. Thomas Paine, en Sentido común, lo explica bien cuando dice que:

La sociedad es obra de nuestras necesidades, y el gobierno de nuestra perversión; la primera promueve nuestra felicidad positivamente al unir nuestras afecciones; el último negativamente, al refrenar nuestros vicios. (Paine 2017, página 5)

Es decir, todos estos son actos y actitudes de inconsciencia e indiferencia hacia los demás, actos y actitudes que, a esos grupos y personas, les solventa su negligencia de negarse a esa verdad la que no deja de ser cierta por mucho que digan o hagan, y que trata de que todos somos parte de una misma dignidad y de una misma humanidad que nos vincula inexorablemente a todos, tanto en interés como en las consecuencias que se provoquen. Y esto es lo que me lleva al siguiente punto.

\section{LA DIGNIDAD DE UNO FRENTE A LA DIGNIDAD DEL OTRO: EMPATÍA DEL RECONOCIMIENTO}

Voy a empezar esta última parte afirmando algo que hay que tener en cuenta como punto de partida para entender el tema de la dignidad en cuanto a su eficiencia en la realidad de cada uno y en cuanto a su eficiencia en la realidad de los demás.

La dignidad humana, de cada uno de nosotros, solo puede alcanzarse si los demás también gozan de la misma. Es decir, para lograr el respeto de mi dignidad humana, la dignidad de los demás también debe de ser respetada $y$, cada uno de nosotros, debemos saber que tenemos que considerar y respetar la dignidad de los demás para que la nuestra se respete y se consiga. No alcanzaremos una dignidad eficiente en nuestras vidas, si no sabemos respetar, promover y proteger la dignidad de los demás. La dignidad del otro, por ese vínculo humano e ineludible que nos une a todos, es también nuestra propia dignidad en tanto sus consecuencias también van de nosotros, también nos competen y también nos tocan, de una o de otra manera, más tarde o más temprano. La dignidad del otro nos importa y nos tiene que importar porque, sin ella, nuestra dignidad no puede alcanzar eficiencia en la realidad. Los seres humanos, tenemos que responder tanto por nuestra dignidad como por la de todos los demás. En este sentido, podemos encontrar filósofos que se acercan y comparten mi visión sobre la dignitas que aquí desarrollo: «Puesto que mi dignidad es la dignidad de todos, también la conducta de mi vida ha de justificarse ante todos» (Brugger y Schöndorf 2014, página 149).

Sobre este, mi punto de vista, quien sigue lo que voy escribiendo en libros y artículos de mi autoría, podrá sentirse familiarizado y encontrar, incluso, coincidencias sobre lo que ya he dicho antes $y$, a veces, sobre otros temas, pero que al tratar de la realidad humana, me llevan a asentar mis argumentos sobre la eficiencia, en la necesidad de contar con una conciencia y convicción sobre el siempre superior valor de nuestra humanidad, de nuestra dignidad humana y de los derechos humanos que buscan promoverla y defenderla. Ahora me toca desenvolver mis argumentos sobre la búsqueda de eficiencia de la dignidad humana $\mathrm{y}$, sostengo, hay que partir de la conciencia y 
convicción de que mi dignidad no será plena ni eficiente si los demás no alcanzan la misma plenitud y eficiencia con la suya. Ahora lo explico.

Está claro que los derechos humanos, buscan alcanzar una misma estructura de unidad moral. No obstante, esta idea estructural de unidad moral-que busca hacer entender a la humanidad como una sola- no resulta suficiente si solo se da en la conciencia y convicción de uno o de unos pocos. Una estructura para que funcione eficientemente depende de la conciencia y convicción de la gran mayoría social de los que la componen. La dignidad humana y su relevancia eficiente, necesitan de la conciencia convencida de la mayoría que integran la estructura social de una comunidad; es decir, no es suficiente ni eficiente que tan solo unos cuantos entiendan a los derechos humanos como superiores, universales e inalienables o que, la dignidad humana, sea un tema que se defienda y regule desde la normativa formal de una sociedad, pero que se estanque en ella sin lograr su respeto y realización real y eficiente.

La humanidad, responde a una realidad de unidad y de conjunto. Esto nos asocia y supedita los unos a los otros; por ello, es necesaria la convicción y la conciencia de respeto hacia la dignidad, los valores y derechos humanos. Sobre todo, en términos de eficiencia, el respeto a la dignidad humana, debe ser entronizado por todos los seres humanos. Esto únicamente se logra con educación, educación y más educación. Y no me refiero a la educación que hoy se preocupa más en producir ciudadanos que se integren al sistema convirtiéndolos en cómplices indiferentes de todo lo malo, pero que se les inculca que ello es todo lo bueno para alcanzar la meta de su triunfo personal y social. De este tipo de educación sesgada, se obtiene ciudadanos intelectualmente mediocres $\mathrm{y}$ fracasados en la potencia, acto y virtud de su existencia, situación que resulta muy cómoda y facilitadora para quien quiera manipular y controlar la conciencia de las masas; los individuos no reflexionan ni se determinan a sí mismos por ser sujetos empoderados, autónomos e independientes -aunque creen hacerlo-, sino que es la conciencia de masa las que los determina; una conciencia de masa que ha sido inculcada, manipulada y educada para someterse, sin percibirlo, a los intereses de determinados grupos de poder. Nuestras sociedades de hoy se llenan de ciudadanos faltos de capacidad crítica e incapaces de advertir lo que se hace con ellos y con todo lo demás que les concierne a ellos. Quienes caen en esta sumisión, logran integrarse con facilidad en el sistema y sienten haber triunfado socialmente porque han seguido las pautas en las que los han educado -domesticados, diría yo-; así, van por la sociedad con semblante de triunfo y pregonando tener una superioridad moral e intelectual con respecto a quienes no se adhieren a su manada; por supuesto, estas personas, realmente, no tienen superioridad alguna con respecto a los que se educan en la reflexión propia y autocrítica sobre todo o que hay. Quien, meramente, se adhiere a la masa se condena a ser una irrelevante herramienta -irrelevante porque puede ser sustituido, de inmediato y sin más, por cualquier otro distraído- para que todo siga igual sin posibilidad de cambio. Son mentes a las que se les mantiene distraídas de su propia realidad e importancia, y a las que se les inculca la aceptación feliz de su propia ineptitud a fin de que coadyuven a la buena marcha de la fábrica que produce a los nuevos e igual de ineptos, necesarios para el sostenimiento de un futuro social sin cambios, sin anhelos y sin reflexiones propias.

Esto es lo que les interesa mantener a determinados e inescrupulosos grupos de poder, ideológicos y de privilegio, que ya se han insertado y logran gran influencia en el poder político estatal. Esta es la manera moderna de colonizar a los sujetos, sobre todo a los de clase media; es la colonización mental de los sujetos: pare qué someter a toda una sociedad, cuando puedes aturdirla con una educación sesgada, e inducirlos a luchar por anhelos de «triunfo» que los hace cómplices y discapacitados para reflexionar por ellos mismos, sobre ellos mismos y sobre todos los demás. Son seres convertidos en deficientes intelectuales, pues se les incapacita para pensar más allá de los que se les inculca, negándoseles el descubrir y el determinar, por ellos mismos, lo que realmente es bueno e íntegro para su existencia humana y lo que realmente los hace seres virtuosos y triunfantes en su vida. Por ello, la correcta educación, la conciencia auténtica de lo que somos y valemos y de lo que es verdaderamente correcto, así como el respeto deferente y sensible por la dignidad humana y por todo lo que hay, no es un tema que se pueda sostener ni cimentar desde el engaño y la manipulación. Es un tema que debe forjarse y fraguarse desde 
la capacidad de crítica obtenida a partir de una indispensable y correcta educación. Nuestro vínculo existencial y substantivo, es lo que hace que se necesite de todos para cambiar y mejorar nuestra existencia. La conciencia y el respeto por la dignidad humana es un deber de todos y a todos nos concierne; no es un tema que se logre alcanzar desde la preocupación aislada de algunos. Es y debe ser preocupación de todos: políticos, gobernantes, poderes y ciudadanos; todos somos necesarios para la consecución de un mundo mejor; es nuestro deber como partes integrantes de una conexa y misma humanidad. Son relevantes aquí las palabras del autor Hartmut Kliemt:

En un mundo en el que los hombres no persiguen siempre por sí mismos el bien de la humanidad, en el que más bien hay que contar con que determinados individuos siempre, y todos los individuos a veces, bajo la invocación del bienestar general lo único que persiguen es su propio bienestar, el concepto de deber tiene un carácter diferente al que podría tener en un mundo de altruistas perfectos. Si un individuo, aisladamente, respeta la paz, no por ello crea un elemento de bienestar general: la paz general. La acción carece de eficacia aún con respecto a su propia persona, ya que el individuo no puede ofrecer ninguna garantía frente a los demás en el sentido de que nunca lesionará la paz. Sigue existiendo la guerra bajo la forma de la inseguridad. No puede dársele fin unilateralmente. (Kliemt 1984, página 65)

Sostengo pues, que es manifiesto que la eficiencia de la dignidad humana es un deber que corresponde ser velado por todos los que nos decimos humanos y que pretendemos vivir sin que nuestro valor como personas, nuestra felicidad y bienestar se vean afectados por intereses inescrupulosos y egoístas.

Existe una estructura existencial de base que nos une y nos vincula a todos con los demás, en tanto, todos y los demás, somos seres humanos. En esta realidad y estructura humana, el eje que guía nuestro respeto y consideración hacia nosotros mismos y hacia los demás, es la conciencia de que todos somos poseedores de una misma dignidad humana como personas $\mathrm{y}$, con ello, poseedores de derechos humanos que hay que respetar y hacer respetar. La dignidad humana es el principio inquebrantable $\mathrm{y}$ determinante para lograr una existencia realmente plena y triunfante; es la base fundamental del avance y mejor desarrollo de nuestras estructuras sociales, presentes y futuras. Todos estamos conectados, unidos y vinculados por nuestra sustantividad humana. Si obviamos o nos negamos a ello, nuestra existencia se complica gravemente en cuanto a la eficiencia real de la puesta en valor de nuestra existencia social: «La estructura no es una sustancia sino sustantividad: pero la unidad de sustantividad es la verdadera y radical condición de lo real» (Legaz y Lacambra 1971, página 73 y 74).

Si bien, no toda norma del Derecho es moral, sí, todas ellas, se construyen a partir de un entendido y una estructura moral del cómo deben ser reguladas las relaciones y la dignidad en una sociedad. Resulta que los derechos humanos cuando protegen y promueven a la dignidad humana, responden a una idea y estructura moral de lo que debe ser protegido como dignidad y como derecho humano. Por ello, es de capital importancia comprender el especial valor que tiene el respeto y protección de la dignidad humana. Es importante entonces, alcanzar una cierta unidad y uniformidad en el entendido del valor que tiene la dignidad humana si es que a ella se le quiere reconocer un talante universal, inalienable y absoluto, para que se pueda exigir una especial protección -en el orden nacional e internacional- al derecho a la vida, a no ser torturado, a no ser desaparecido forzadamente, al derecho a la educación, etcétera. Se afirma que estos son derechos morales que todos entendemos que deben ser inquebrantables y, por ello, se asientan normativamente, en los llamados derechos humanos, a través de convenios, declaraciones e instrumentos internacionales de todo tipo. Contar un entendimiento moral, conceptual y compartido, sobre lo que es la dignidad humana, es fundamental para todo orden social que pretenda ser civilizado y correcto. Sin embargo, en la actualidad somos testigos de que es, nada más y nada menos, desde el orden político estatal que el orden moral de la dignidad humana y de los derechos humanos parecen menospreciarse y desplomarse para dar paso y preferencia a otros intereses de privilegio y poder. Pese a todo, debe saberse que esta situación es incapaz de subsistir en el tiempo porque no hay sociedad ni nación que sobreviva, ni orden social que se mantenga en buen estado si no sabe respetar 
y prestar atención prioritaria a su existencia y valor humano, es decir, a la dignidad humana $\mathrm{y}$ al orden moral de la los derechos humanos de todos: «(...) todo lo más que se puede exigir a las naciones en sus mutuas relaciones es que respeten ciertas virtudes, como las de la humanidad, disposición hacia la paz (...)» (Villey 2016, página 53).

Todos tenemos el deber de cuidar de nuestra humanidad $\mathrm{y}$, como ciudadanos, tenemos el deber de mantener una actitud vigilante y constantemente reflexiva que nos permita ejercer un juicio crítico sobre lo que los Estados, a través de sus poderes instituidos, determinen políticamente para nuestras vidas y las connotaciones que estas determinaciones impliquen para los demás. La atención activa y constante de lo que hacemos y de lo que sucede a nuestro alrededor, es nuestro deber como seres que somos dotados de razón y con capacidad de determinación. Los sujetos que, cómodamente, se dejan llevar por todo aquello que le dicen que está bien o que, simplemente, aceptan que las cosas no se pueden cambiar porque le han dicho que siempre ha sido así o que si se cambia se afectarían a otros intereses mayores, son sujetos detestables, reprochables y menospreciados en sus capacidades. Este tipo de sujetos son los que, precisamente, facilitan que determinados poderes estatales y los poderes fácticos puedan obviar su respeto y su atención hacia la dignidad humana relegando la protección de los derechos humanos a un segundo plano o, simplemente, ignorándolos por completo. Los ciudadanos distraídos, poco educados o los que se centran en ideologías oportunistas y en radicalismos, son dañinos para la sociedad. Estos últimos, creen que defienden sus derechos o que defiende los de un determinado grupo social, cuando realmente no son más que meros instrumentos de distracción para que determinados grupos de poder o sus líderes oportunistas, saquen el mayor rédito para sus intereses particularistas. Pedro Gago Guerrero dirá:

El dominio se ejerce por la ausencia de contestación, (...) debido a la ignorancia sobre lo que está pasando, siendo lógico que el elector tenga dudas sobre la capacidad para escoger lo más adecuado. Dado que la libertad política aparece muy esporádicamente, el régimen político podría ser calificado de amable despotismo. Se ha llegado a formar porque la estrategia del Poder consistirá en dominar invisiblemente mermando la capacidad soberana de la sociedad, con las excepciones generalmente debidas al procedimiento, quedando en ocasiones algún resquicio para conseguir cierta justicia y ralentizar la caída en la tiranía (Gago 2013, página 104).

Nuestra actitud frente a los demás debe ser responsable y esforzada; los poderes imperantes no nos deben forzar ni nos debemos dejar forzar ni llevar, para, simplemente, integrarnos en todo lo que hay y así evitarnos el ardor de cambiar las cosas y de ser correctos en el ejercicio de nuestros actos. Esta responsabilidad se enmarca en la convicción de la superioridad de los valores, dignidad y derechos propios de la humanidad. No se trata de evitar nuestros problemas propios a costa de desatender nuestro deber para con los demás; esto es inaceptable y completamente insensato. Es, desde una ética de la convicción, conseguida con una buena educación, lo que nos lleva a ser realmente responsables en el ejercicio de nuestras determinaciones de vida. Las convicciones se forjan con la buena educación en valores y derechos ciudadanos, de ahí que esta sea de especial relevancia en el desarrollo de nuestras sociedades. Un mundo sin una educación que impulse la capacidad de reflexión y de crítica de sus ciudadanos, sin una educación en valores, está condenado a convertirse en un mundo injusto, insolidario y desigual y, con ello, en un mundo, a la larga, insostenible. Por ello, es de crucial importancia forjar la exigente conciencia de que todos pertenecemos a una misma unidad común, representada en la humanidad y en la dignidad de todos los seres humanos, sin excepción. Existe una fuerza trascendental y determinante de nuestra realidad y de nuestras determinaciones; esta es una fuerza trascendental, determinante y concreta. La concreción de esta fuerza se encarna en el propio ser humano. Somos los seres humanos lo concreto de la fuerza que decide el destino de nuestras sociedades. Estaré en desacuerdo con el filósofo Martín Heidegger, pues se equivoca cuando niega la importancia de nuestra capacidad de pensar. Heidegger afirma que: «Lo que más merece pensarse en nuestro tiempo problemático es el hecho de que no pensamos») (Heidegger 2005, página 17). Por el contrario, estaré de acuerdo con las afirmaciones de Ortega Gaisán: 
La inteligencia humana apunta (...) el primer hito para la grandeza humana. Tus pensamientos: eso eres tú. (...) Lo que cada hombre lleva en su cabeza, eso importa sobre todo y, antes que nada. (Ortega 1958, página 273)

Somos los seres humanos los que, pensando y reflexionando, determinamos lo que sucede en nuestras sociedades; somos los llamados a ejercer nuestras fuerzas y capacidades concretas para interesarnos por el respeto de nuestra dignidad y la de los demás. La historia y la realidad no sobrevienen mecánica y automáticamente impuestas; la verdad del desarrollo y evolución de nuestra existencia radica en que somos los seres humanos los que las decidimos en uno $u$ otro sentido; por ello, nuestras decisiones deben ser siempre responsables y conscientes: «(...) vivir es constantemente decidir lo que vamos a ser» (Ortega y Gasset 1984, página 195). Pero si nos convencemos o nos dejamos convencer y nos convencen, de que no somos capaces de decidir nuestro destino, de que nuestra dignidad es sacrificable frente a determinados intereses, de que la dignidad de los demás importa poco o nada y de que ello no nos va afectar a los demás, entonces, los sujetos de la sociedad dejan de ser libres, dignos y valiosos. Se convierten en sujetos instrumentalizados, en sujetos menospreciados y condenados a ser manipulados y decididos por otros. Son sujetos que caen en el desánimo y que se convencen que el mundo no puede cambiar o, lo que es lo mismo, que se ha deteriorado tanto que es imposible poder superar todos sus males y, por lo tanto, no queda más que resignarse e integrarse a él tal cual está, sin importar que esto suponga que obremos mal y en detrimento de los demás. Ahora bien, es cierto que cada uno de nosotros no decidimos nacer; no obstante, ello, una vez que estamos en este mundo y según nos vamos desarrollando, tenemos la inquebrantable responsabilidad de vivir según nos corresponde y no según se nos antoje, descuidada o distraídamente. Esta responsabilidad es trascendental si queremos hacer honor a lo que somos y a nuestro valor humano, que es el mismo que poseen todos los demás -los otros- quienes no nos son ajenos por la sustancialidad humana que compartimos con todos. Si negamos esto, caeremos en un estado de displicencia y desaliento sobre nuestra propia existencia, lo que facilitará que podamos ser manipulados y sometidos al capricho de cualquier interés inescrupuloso, si quien con un poco más de habilidad se dé cuenta de nuestra detestable debilidad. Debemos, antes que nada, saber reconocernos a nosotros mismos para así saber, conscientemente, el valor que tenemos como seres humanos $y$, con ello, sabremos el valor y el respeto que merecen todos los demás; esta es la moral y el espíritu que debe guiarnos durante toda nuestra existencia, y es esto lo que realmente enaltece nuestra dignidad y nos hace crecer como sujetos, al sabernos y entendernos como somos seres vinculados a los demás -a los otros-. Es esta la convicción que tenemos que entronizar para alcanzar una vida de bien:

Los bienes culturales, espirituales, de orden moral, unen y, en lugar de agotarse, crecen a medida que se distribuyen. Pero la adhesión a esos bienes se debe realizar primero en la relación consigo mismo. El caso extremo del bárbaro, o del hombre perverso, lo ilustran a contrario, pues son inmediatamente rechazados por aquel que está tan dividido contra sí mismo que ya no tiene un yo verdadero al que amar y detesta todo lo que en él encuentra, empezando justamente por su humanidad. (...) El ser humano integro (...) es un experto en humanidad (...) está en condiciones de ver en todo hombre o en toda mujer (otro yo). (De Konick 2006, páginas 205-207)

Por ello, no nos podemos permitir caer en la barbarie y en la perversión hacia el respeto de nuestra humanidad. Los seres humanos deben crear su felicidad afirmando la justicia y luchando contra la injusticia, negándose a caer en el mundo del engaño y del infortunio. Tenemos, todos, la responsabilidad de estar siempre alertas y seguros de la deferencia y del valor que merece nuestra existencia y la de cada ser humano. Aunque también es cierto, que este deber del sostenimiento digno y responsable de nuestra existencia, a las masas populares, cada vez les cuesta más defenderlo y mantenerlo en el ejercicio de sus vidas. Las masas se vuelven cómplices de su sometimiento por esa desidia y no asunción de su deber responsable. Esto les resulta ociosamente mucho más cómodo, aunque con el tiempo inaceptable ya que les significa vivir en el engaño de su verdadero valor y en el desprecio de ellos mismos; con el tiempo se quedan sin fuerzas o se pierden en el engaño y ya no logran levantar cabeza para sentirse dignos de lo que son. En este escenario, 
son determinadas personas las llamadas a hacer algo; son escasas, es cierto, pero son las que asumen su responsabilidad y mantienen su capacidad para defenderse y hacer respetar su dignidad frente al abuso que alguien pretenda ejercer en contra de ellos. Además, son estas determinadas personas las llamadas a hacer despertar a esas masas distraídas en su error; luego, ellas -las masas despertadasseguirán a quienes los despiertan y así, se darán los grandes cambios de la historia de la humanidad. Esta es la responsabilidad que nos toca a quienes sabemos que vivir implica un ejercicio consciente y esforzado de cada uno de nuestros actos; quienes asumen esta responsabilidad son los verdaderos líderes de nuestra sociedad. En opinión semejante, nos encontraremos a Ernst Bloch cuando dice que:

Nadie vive porque quiere. Pero, después de que se vive, hay que querer seguir viviendo, Y hay que seguir fiel a ello, si se quiere llegar a algo. (...) Calladamente se acostumbra uno al látigo, y de los oprimidos no surge así, sin más, ese clamor que se articula y pone en pie. Sólo individuos aislados se alzan, en un principio, contra los usos (...) y los siervos enfurecidos sólo más tarde se han agrupado para la revuelta. (Bloch 2011, páginas 53 y 60)

El desánimo no puede ser el impulso motor que mueva el ejercicio de nuestras decisiones y determinaciones, sobre todo de cara al respeto de nuestra dignidad y de los derechos humanos que la cubren. Hay que tener la convicción de que lo imposible es posible para los seres humanos $\mathrm{y}$, sobre todo, para los que actúan con determinación, fe y responsabilidad. El convencimiento de un mundo mejor, es una suerte de arrebato y frenesí que cree y siente que, ante la adversidad, todo cambio a mejor es siempre posible:

Es completamente cierto, y toda la experiencia histórica lo confirma, que no se conseguiría lo posible si en el mundo no se hubiera recurrido a lo imposible una y otra vez. Pero para poder hacer esto un líder, y no sólo esto sino un héroe, en un sentido muy sobrio de la palabra. Y quienes no sean ambas cosas también deberán armarse con esa firmeza de corazón que permite hacer frente al fracaso de todas las esperanzas, y deben hacerlo ya, pues si no, no estarán en situación de realizar siquiera lo que hoy es posible. (Weber 2018, página 151-152)

Entonces, para preservar la dignidad humana es imprescindible contar con una conciencia y convicción sobre los valores superiores de nuestra humanidad. Esta conciencia moral y convicción nos exigirá ser responsables con nuestras decisiones y no permitirá que ejerzamos nuestros actos desatendiendo, irresponsablemente, nuestro comportamiento en relación a las personas y a sus derechos.

Puede ser cierto parecer que resulte más fácil vivir sin preocuparnos por la afectación de la dignidad humana de los demás -sin poner atención en sus problemas de pobreza, de desigualdad o de auxilio a quienes huyen del terror o de la guerra, etcétera-, no obstante, el vínculo de humanidad que nos une a todos, nos impide eximirnos de las consecuencias de nuestra desatención y de nuestra falta de asunción de responsabilidad, atención y solidaridad para con los demás. El respeto e interés a los derechos y a la dignidad de uno y el respeto e interés por los derechos y por la dignidad de los demás, es algo que hay que tomar muy en serio: «(...) tomarse los derechos en serio (...) supone reconocerles existencia y carácter normativo y vinculante (...) una dignificación, por la vía de la responsabilización (...)» (Squella 2010, página 51). Seres humanos inmóviles e inoperantes para reaccionar críticamente ante la conculcación de sus derechos, son seres humanos sucumbidos al sentimiento de la absurdidad y al de la irrelevancia existencial.

El problema ajeno tiene que ser tratado como un problema propio ya que, en la realidad de nuestra humanidad, lo ajeno no existe. Hay que poner en práctica eso que he dado en llamar como la teoría de la empatía del reconocimiento. Con esta teoría planteo, que todos debemos saber reconocernos en todos, en todos los demás o, si se quiere, en los otros, pues esos otros también somos nosotros. Como lo explicaba en obras anteriores (Contreras 2018, página 281), con la teoría de la empatía del reconocimiento doy un paso mayor, más ambicioso y sustancial que el de la simple empatía. No se trata de una situación abstracta, de mera solidaridad o de bondad. Se trata de una propuesta que se concreta en nosotros mismos, en nuestras realidades y que lleva consigo el interés, el de cada uno y el de todos, 
de vivir en un mundo mejor. El otro no es un ajeno. Cada uno de nosotros no somos seres impermeables a los demás; los otros son parte nuestra desde un principio. El poeta Arthur Rimbaud, acertaría, en lo que se conoce como Carta del vidente (Rimbaud 2010, página 61), cuando afirmaba que yo es otro:

(...) el poeta tiene razón: yo es otro. $\mathrm{La}$ pluralidad interior de cada ser es el correlato de la pluralidad de las personas que lo rodean (...) El sí mismo es el producto de los otros que, a su vez, éste produce. Esto no significa que el ser humano no tendrá nunca acceso a lo que los filósofos llaman la autonomía. (Todorov 1995, páginas 176 y 177)

Nuestro vínculo mayor, cierto e inexcusable, es la humanidad, y ella nos une a todos en el devenir y en la realidad a la que haga frente cada sociedad. Esto es parte de nuestra espiritualidad natural que desvela nuestro superior y más atento ser intelectual, y nos potencia a entender la realidad en su cabal y veraz medida. Gracias a esa espiritualidad humana, nos sabemos, nos preocupamos y nos entregamos al otro de manera natural. Son los despistes en los que caemos y todo ese bullicio de banalidades que atiborran hoy nuestras cabezas, las que nos hacen creer que somos el centro autosuficiente del todo y que no requerimos creer ya en nada ni en nadie, más que en nuestra aislada particularidad singular de individuos. Todo ello, es lo que nos aleja de la virtud y nos pierde de nuestra propia naturaleza espiritual y humana, desconectándonos y cerrándonos a los demás. Lo cierto es que, en la idea de unidad humana, todos somos parte integrante de lo mismo -de la misma humanidad- y nos une un mismo interés de bienestar, dignidad y desarrollo. Negarse a ello, más tarde o más temprano, en mayor o menor medida, nos termina perjudicando a todos, justamente, por esa verdad de conjunto, vinculación y unidad, que es la que nos une obligatoria, inevitable, forzosa y necesariamente a todas personas, por la sola, esencial y propia condición de seres humanos que a todos nos envuelve y determina:

Sabernos y sentirnos parte del otro, por nuestro ser espiritual, nos lleva a reconocernos como parte importante de una obra mayor donde los «otros» son parte de esa misma obra y por ello merecen nuestra atención y respeto. (Contreras 2018, página 145)
Somos seres que en principio nos abocamos a nosotros mismos, pero, una vez que nos entendemos parte de un todo y de los demás, por esa vocación natural de amor propio, pasamos a sabernos y a sentirnos como una vocación de amor y de respeto hacia los demás. En este entender, nuestro ser se libra de los impedimentos y de las trabas que trastornan nuestra mirada de amor al otro, y así, nos permite verlo como lo que es: el amor a nosotros mismos. Considerar, respetar y entregarse a los «otros», es considerarse, honrarse y entregarse a uno mismo. En este orden de ideas, recuerdo aquí las palabras de don Evaristo Palomar Maldonado, cuando explica el cómo se da esa inapelable y contundente vocación de apertura que tenemos los seres humanos, la que:

(...) es una vocación de donación, de darse a sí mismo. De modo que en su donarse brota una comunidad personal. Dicha donación en cuanto lo es con una vida semejante lo que busca es la misma comunicación (...) que es comunicación interpersonal (...) esto es lo que satisface al hombre y a la mujer, como su propio bien, vivir con los demás, y que es el fruto de la amistad. Toda amistad es manifestativa del amor interpersonal: «El amor pide la convivencia). (Palomar 2001, página 67)

Debemos forjar sociedades que tengan unidad de sentimientos y unidad de deberes, con convicciones fundadas en los valores que nos hacen personas de bien. Como bien apunta el filósofo Jonas Cohn: «(...) la unión de la voluntad más pura y del conocimiento de nuestras energías nativas y de la cohesión y relación histórica de ambas, esa es también nuestra misión» (Cohn 1927, página 188). Nuestro ser existencial hay que mantenerlo estimulado y hay que incitar al de los demás para que no nieguen la potencial virtud que nos es propia a todos como seres humanos. Somos seres capaces e inteligentes; no obstante, no somos lo suficientemente vastos y completos como para suponer que nuestra existencia se logra auto-resolver solo en nosotros mismos. Somos grandes y excelsos en importancia y dignidad, pero lo somos, en tanto nos debemos y somos parte de una creación superior que, aunque, nos ha dado la capacidad del libre albedrio, esta capacidad está allí para darle sentido, plenitud y trascendencia a nuestra existencia. Creer en la trascendencia concreta de nuestra existencia, según nuestros actos $\mathrm{y}$ 
determinaciones, no es solo un acto de fe, es también un acto de inteligencia y de sensatez existencial. Existir bajo la insensatez de creer que todo se reduce al día a día y hasta el día de nuestra muerte, o creer que todo se reduce a nuestra humanidad individual y que nuestros actos no tienen mayor significación y trascendencia más allá de nuestra existencia terrenal, solo nos conduce a la desestimación $\mathrm{y}$ menosprecio de nosotros mismos $\mathrm{y}$, con ello, a la desestimación y menosprecio del que tenga al frente, es decir, a la desestimación y menos precio de todos los demás. La fatal consecuencia de creernos lo anterior, nos lleva a un engaño que nos exige ocultarnos de nosotros mismos. Y la mejor manera de lograr este engaño y tapadera de nuestra indefectible verdad, es dejarnos llevar por todas esas superficialidades que nos impone el sistema de hoy a fin de convencernos de que ese es el verdadero sentido que tiene nuestra vida. Quien tome decisiones en este estado de engaño y confusión, no tomará en cuenta la dignidad humana ni el derecho de los demás pues su único fin es no perder el sentido superfluo que le han impreso a su vida; este tipo de personas, en su insensatez, no podrá respetar la dignidad de los demás, pues no respeta propiamente la suya y cree que lo único que tiene que defender, por encima de todo y de todos, es el sostenimiento de esas metas de triunfo particularistas y egoístas que lo alejan y desvinculan de su verdadero valor humano y del de los demás:

El verbo engañar (...) en la realidad de la vida cultural o social, resulta ser un verbo reflexivo; por lo que acaba expresando una acción que recae sobre el mismo sujeto, y se refleja en su viciosa, vacua, o vacía alma. (Pascual 1969, página 72)

Estas personas, únicamente se entenderán vinculadas a sí mimas -sin darse cuenta que realmente están encerradas y presas de ellas mismas-. Es caer en el delirio del descontrolado y desmedido interés propio, que siempre nos lleva a creernos por encima del interés general. Es el despropósito de convertirnos en sujetos auto-divinizados en nuestra superficialidad y engaño. Es creernos autosuficientes para desarrollar nuestras vidas, lo que, al ser imposible por nuestra humana naturaleza, luego nos desvincula de nosotros mismos y, claro está, también de los demás.
Hoy nos enfrentamos a una realidad en la que encontramos demasiados seres humanos perdidos en sí mismos y esforzados por eludir su verdad existencial, aunque nunca escapando de ella. Por ello, afirmo que es deber de todos el creer en nuestra vida y en su verdad y valor; ella sí tiene una trascendencia concreta y superior:

La vida moral es creativa. (...) Crea, mediante los valores, un tipo de vida. Éste se decide en el momento mismo de optar por unos valores u otros, es decir, de ponerse en la estela de una vitalidad ascendente, o bien del lado de una vitalidad descendente. En este segundo caso habremos renunciado a la vida moral creativa. Esta oposición original en necesaria e insuperable. (Bilbeny 1990, página 99)

Cada uno de nosotros somos capaces, con la fuerza de nuestra razón y del libre albedrío, de determinarnos para el bien o para el mal. Tú tienes el poder de tomar, de cambiar y de elegir lo que quieres hacer en tu vida y con tu vida. Sabiéndote parte de algo mayor y concreto, que, aunque superior, te guía, te llena y le da paz al sentido de tu vida. No te digo en qué o en quién has de creer -sobre todo porque no es ese el objeto de este trabajo-; sin embargo, has de saber que debes creer en algo superior que guíe tu vida, empezando por tu propia humanidad. Sé asidua y perseverantemente correcto, cauteloso y precavido para no hacer daño ni perjudicar a los demás, ni directa ni indirectamente. Si cometes un error, has de saber que deberás reconocerlo, repararlo $\mathrm{y}$, además, sufrirlo en sus consecuencias; son tres estadios necesarios e inevitables para poder continuar dejando atrás aquello en lo que te equivocaste. Mientras tengas aliento, vigor y sensibilidad para celebrar tus éxitos y sufrir tus penas, para sentir tus alegrías, triunfos y derrotas, sigues teniendo la oportunidad de enmienda. Eso solo se logra creyendo concretamente en algo más grande que tú, que sea capaz de entender, corregir y perdonar lo que tú mismo no entiendes, no corriges ni sabes perdonar, desde tu propia humanidad, de ti mismo ni de los demás:

Así como no apreciamos el valor del aire, o el de la salud hasta que nos hallamos en un ahogo o enfermos, así al hacer aprecio de una persona olvidamos con frecuencia 
el suelo firme de nuestro ser, lo que todos tenemos de común, la humanidad, la verdadera humanidad, la cualidad de ser hombre (...). (De Unamuno 1967, página 11)

Eres parte de un todo y ese todo superior es lo que te hace grande como persona; si te desvinculas, niegas o atentas contra ese todo, te niegas a ti mismo y te empequeñeces en espíritu, valor y virtud. Ser indiferente a los peligros y males que afrontan los demás, a los peligros y males que atentan con la dignidad de los «otros», es condenarse uno mismo al abandono de su ser interior y, con ello, al abandono y a la pérdida de su valor real y propio de ser humano; se cae en lo que reza ese antiguo adagio de la llamada moral primitiva: «El que abandona á su semejante en el peligro, participa de su pérdida» (D.R.C. 1858, página 5).

\section{CONCLUSIONES}

Luego de lo que he desarrollado, sigo convencido de que el mundo en el que vivimos posee un gran sentido concreto, y ese sentido se encarna en el propio ser humano ya que es él quien, principalmente, determina el rumbo del mundo y es él quien se preocupa por pensar en ese sentido. Las sociedades no deben su existencia a una generación espontánea o abstracta; somos los seres humanos los que las conformamos y decidimos de manera concreta. Una sociedad no existe ni funciona sin nosotros; he ahí nuestra crucial importancia. Esta verdad no solo nos reviste de derechos sino también de deberes y responsabilidades. La dignidad humana no es un obsequio que se sostenga por sí misma y sin más; la dignidad, hay que respetarla con el esfuerzo consciente de cada uno y con el esfuerzo de todos. Y es que la necesidad de respeto a la dignidad humana, nos es común a todos. El respeto hacia la dignidad humana, es donde debemos de afirmarnos como seres humanos, extendiendo esto como una realidad de superior valor de todos y de todo:

Al mantener la belleza, preparamos ese día de renacimiento en que la civilización pondrá en el centro de su reflexión (...) esa virtud viva que funda la común dignidad del mundo y del hombre. (Camus 2013, página 35)
Es solo el ser humano, el ser dotado del poder y de la potencia, necesarias para alcanzar la conciencia real del valor de su existencia; es él quien puede alzarse sobre el mundo a través de sus capacidades racionales y mediante el buen cultivo de sus convicciones y de su alma. Esto es lo que lo diferencia del resto de seres vivos que conviven con él. La conciencia y la convicción del superior valor de su dignidad humana, es lo que lo determina como un ser libre de la ignorancia existencial, y es lo que lo libera del yugo y de la tiranía del engaño. La conciencia educada y convencida de ello, es la fuerza suficiente para evitar caer en los vicios de la ignorancia y del engaño. Una vez se es consciente del valor de la dignidad humana, ya no es posible dejar la evidencia de esa verdad pues esa conciencia le permitirá, al ser humano, advertir la manipulación y el engaño, impidiendo la indiferencia y el engañarse a sí mismo sobre lo que es y debe ser correcto. Quien es capaz de ser indiferente a su dignidad y la de todos los demás, se engaña a sí mismo y cae en una debacle existencial de sí mismo, de menosprecio e irrelevancia propia.

Negarse a la necesidad existencial de respeto a la dignidad humana, es caer en la inconsistencia de un juicio profundamente corrompido y depravado. Lo cierto, es que la voluntad y la potencia de los seres humanos son fuerzas que no se pueden medir ni menospreciar, y este es un hecho que nos es común a todos pues es propio de nuestra humanidad. A veces parece que la conciencia sobre la dignidad humana se ensombreciera, a tal punto de arrancársele su protagonismo y de hundirla, incluso, a un estado de grosera irrelevancia. $\mathrm{Y}$ es que, en la actualidad, pareciera que no es suficiente tener la condición de ser humano para gozar de dignidad y respeto. Hay, además, que destacarse, de cualquier modo, sobre todos los demás, como si tuviéramos que preocuparnos por revestirnos de una tasación con las que se nos precie como seres socialmente respetables y dignos de tener dignidad. De no alcanzar la tasación mínima necesaria, los sujetos sienten caer en oquedad del envilecimiento y la desgracia existencial; por ello, estarán dispuestos a hacer lo que sea para evitar caer en ese estado de bajeza, incluso, ante ese pavor que se les inculca, estarán dispuestos a ser parte del engaño y de la manipulación. En realidad, lo que guía sus vidas, es más el miedo a no caer en ese estado, que el ánimo mismo de lograr un respeto tasado de digno. En este 
escenario, el ser humano íntegro tiene poca o ninguna cabida; quien posea una personalidad sana, se negará, indubitablemente, a esta deformación mala y ridícula de la existencia y en contra de la dignidad. Lo verdadero y lo profundo de nuestra existencia es lo que nos es común a todos, es lo que nos integra a todos sin distinciones superficiales de valor o precio tasado. La vida de algunos no es un mero instrumento para mantener el disfrute de la vida de otros. El pavor a quedar degradados y a ser ignorados por las distinciones tasadas que la sociedad de hoy impone, hace que obviemos la importancia de la dignidad humana, hace que la olvidemos; el ser humano queda reducido al valor de ser apreciado, sobre todo, por la producción de riqueza económica que alcance en su vida.

Por ello, y finalmente, afirmo que el ser humano es una fuerza integradora inconmensurable, siempre que no caiga en el engaño y en la manipulación de su existencia. El verdadero fin de todo ser humano, es su vida y, con ello, la conservación y el respeto de su dignidad. La conciencia de esto, es lo que le lleva a saber que su dignidad es la misma que la de lo demás y que, siendo así, debe y tiene que también respetarla. Este es el mayor valor y el más intenso de su existencia; es lo que lo completa en su humanidad. No se trata de destacar sobre todos los demás para sentirse relevante y superior. Toda obra y posición destacada que se alcance, cuanto más grande sea, debe alcanzar la mayor satisfacción de ofrecerse al bien de los demás y de la sociedad en su conjunto. Las distinciones de nuestras vidas no se alzan ni se enaltecen en nosotros mismos; si la dejamos allí y nos regocijamos en ello, más bien terminan corrompidas y nos pierden en el engaño. Toda distinción que alcancemos hay que brindarla al bien de los demás, en bien del prójimo. Esta es la grandeza de nuestra existencia, lo que nos hace seres plenos y dignos; entregarnos a la dignidad, a la atención y al respeto de los demás -al otro- es entregarnos a nosotros mismos.

\section{FUENTES DE INFORMACIÓN}

\section{Fuentes bibliográficas}

Bilbeny, Norbert (1990). Humana dignidad. Madrid, España: Tecnos.
Bloch, Ernst (2011). Derecho natural y dignidad humana. Traducido por Felipe González Vicén. Madrid, España: Dykinson.

Brugger, Walter y Schöndorf, Harald (2014). Diccionario de filosofía. Traducido por Raúl Gabás. Barcelona, España: Herder.

Camus, Albert (2013). Breviario de la dignidad humana. Traducido por Elisenda Julibert. Barcelona, España: Plataforma.

Cohn, Jonas (1927). Los grandes pensadores. Introducción histórica a la filosofía. Traducido por Domingo Miral. Barcelona, España: Labor.

Contreras Ugarte, Jesús Víctor Alfredo (2018). Las determinaciones políticas en materia de derechos humanos. Cavilaciones a partir de la ética weberiana y de la fuerza trascendental hegeliana. Berlín, Alemania: Editorial Académica Española.

Contreras Ugarte, Jesús Victor Alfredo (2018). Realidad, poder, valores y derechos humanos: el poder dominante en Max Weber. Madrid, España: Facultad de Derecho Universidad Complutense de Madrid.

D.R.C. (1858). Tesoro de la sabiduría. Madrid, España: Ramón Campuzano.

De Koninck, Thomas (2006). De la dignidad humana. Traducido por María Venegas Grau. Madrid, España: Dykinson.

De Unamuno, Miguel (1967). La dignidad humana. Madrid, España: Espasa-Calpe.

Della Mirandola, Pico (1978). Discurso sobre la dignidad del hombre. Traducido por Adolfo Ruiz Díaz. Buenos Aires, Argentina: Goncourt.

Descartes, René (1982). El discurso del método. Traducido por Fernando Alonso. Madrid, España: Akal.

Fichte, Johan (2015). «Discurso a la nación alemana». En Fichte. Traducido por Ángel Juan Martín. Madrid, España: Gredos.

Fichte, Johan (2011). El destino del hombre. Traducido por Juan Ramón Gallo Reyzábal. Salamanca, España: Sígueme.

Fichte, Johan (2015). "Fundamento de toda la doctrina de la ciencia». En Fichte. Traducido por Juan Cruz Cruz. Madrid, España: Gredos. 
Gago Guerrero, Pedro Francisco (2013). El Estado social y el ciudadano. Madrid, España: Difusión Jurídica y Temas de Actualidad.

García Cuadrado, José Ángel (2013). Grandeza y miseria humana. Una lectura del Diálogo de la dignidad del hombre (Fernán Pérez de Oliva). Pamplona, España: EUNSA.

García Gibert, Javier (2010). La humanitas hispana. Sobre el humanismo literario en los siglos de oro. Salamanca, España: Universidad.

Gracián, Baltasar (2007). El criticón. Editado por Elena Cantarino. Madrid, España: Espasa Calpe.

Habermas, Jürgen (2018). El futuro de la naturaleza humana ¿Hacia una eugenesia liberal? Traducido por R. S. Carbó. Barcelona, España: Paidos.

Heidegger, Martín (2005). ¿Qué significa pensar? Traducido por Raúl Gabás. Madrid, España: Trotta.

Kant, Inmanuel (2018). «Crítica de la razón práctica». Traducido por Roberto Rodríguez Aramayo. En Kant. Volumen II. Madrid, España: Gredos.

Kliemt, Harmut (1984). Filosofía del Estado y criterios de legitimidad. Traducido por Ernesto Garzón Valdés. Barcelona, España: Alfa.

Legaz Y Lacambra, Luis (1971). Problemas $y$ tendencias de la filosofía del derecho contemporánea. Madrid, España: Fundación Valdecilla.

Menke, Crhistoph Y Pollman, Arnd (2010). Filosofía de los derechos humanos. Traducido por Remei Capdevilla Werning. Barcelona, España: Herder.

Millán-Puelles, Antonio (1984). Léxico filosófico. Madrid, España: Rialp.

Ortega Gaisán, Alejandro (1958). Valores humanos. Volumen III. Vitoria, España: Industria Gais.

Ortega Y Gasset, José (1984). ¿Qué es filosofía? Madrid, España: Espasa-Calpe.

Paine, Thomas (2017). El sentido común y otros escritos. Traducido por Ramón Soriano y Enrique Bocardo. Madrid, España: Tecnos.
Palomar Maldonado, Evaristo (2001). Sobre la tradición. Significado, naturaleza y concepto. Barcelona, España: Balmes.

Pascual Ferrández, Antonio (1969). Conciencias inconcientes. Barcelona, España: Peñíscola.

Pérez De Oliva, Fernán (1927). Dialogo de la dignidad del hombre. Madrid, España: Compañía Ibero-Americana de Publicaciones.

Pascual Ferrández, Antonio (1927). «Discurso de las potencias del alma y del buen uso delladignidad del hombre. Madrid, España: Compañía Ibero-Americana de Publicaciones.

Rimbaud, Arthur (2010). Carta del vidente. Traducido por Marco Antonio Campos.

Bogotá, Colombia: Fundación Común Presencia.

Schiller, Friederich (1962). De la gracia y la dignidad. Traducido por Juan Probst y Raímundo Lida. Buenos Aires, Argentina: Nova.

Sloterdijk, Peter (2018). ¿Que sucedió en el siglo XX? Traducido por Isidoro Reguera. Madrid, España: Siruela.

Squella, Agustín (2010). Derechos humanos: ¿invento o descubrimiento? Madrid, España: Fundación Coloquio Jurídico Europeo.

Todorov, Tzvetan (1995). La vida en común. Ensayo de antropología general. Traducido por Héctor Subirats. Madrid, España: Taurus.

Torralba Roselló, Francesc (2017). ¿Qué es la dignidad humana? Barcelona, España: Herder.

Veronesi, Paolo (2015). «La dignidad humana: una idea aparentemente clara». Traducido por Yolanda Gomez Lugo. En Dignidad humana $y$ derecho fundamental. Dirigido por Ricardo Chueca. Madrid, España: Centro de Estudios Políticos y Constitucionales.

Villey, Michel (2016). Filosofía del derecho. Traducido por Evaristo Palomar Maldonado. Madrid, España: Tradere.

Weber, Max (2018). La política como profesión. Traducido por Joaquín Abellán. Madrid, España: Biblioteca Nueva. 